\title{
Article \\ Chicken Feather Keratin Peptides for the Control of Keratinocyte Migration
}

\author{
Cláudia M. Botelho ${ }^{1, *} \mathbb{C}^{\circledR}$, Pedro Ferreira-Santos ${ }^{1} \oplus$, Duarte Toubarro ${ }^{2}$, Hugo Dinis ${ }^{1}$, Hugo Osório ${ }^{3,4,5}{ }^{\circledR}$, \\ Augusto Costa-Barbosa ${ }^{6}$, Paula Sampaio ${ }^{6}\left(\mathbb{D}\right.$, Nelson Simões ${ }^{2}$ and José A. Teixeira ${ }^{1}$ (D) \\ 1 Centre of Biological Engineering, Universidade do Minho, 4710-057 Braga, Portugal; \\ pedrosantos@ceb.uminho.pt (P.F.-S.); hugodinis12@gmail.com (H.D.); jateixeira@deb.uminho.pt (J.A.T.) \\ 2 CBA-Biotechnology Centre of Azores, Faculty of Sciences and Technology, University of Azores, \\ 9500-321 Ponta Delgada, Açores, Portugal; duarte.nt.tiago@uac.pt (D.T.); nelson.jo.simoes@uac.pt (N.S.) \\ 3 i3S-Instituto de Investigação e Inovação em Saúde, Universidade do Porto, 4200-135 Porto, Portugal; \\ hosorio@i3s.up.pt \\ 4 Ipatimup-Institute of Molecular Pathology and Immunology, University of Porto, 4200-135 Porto, Portugal \\ 5 Department of Pathology, Faculty of Medicine, University of Porto, 4200-319 Porto, Portugal \\ 6 CBMA-Centre of Molecular and Environmental Biology, Department of Biology, University of Minho, \\ 4710-057 Braga, Portugal; augusto.ac.barbosa@gmail.com (A.C.-B.); psampaio@bio.uminho.pt (P.S.) \\ * Correspondence: claudiabotelho@deb.uminho.pt
}

Citation: Botelho, C.M.;

Ferreira-Santos, P.; Toubarro, D.;

Dinis, H.; Osório, H.; Costa-Barbosa,

A.; Sampaio, P.; Simões, N.; Teixeira,

J.A. Chicken Feather Keratin Peptides for the Control of Keratinocyte

Migration. Appl. Sci. 2021, 11, 6779.

https://doi.org/10.3390/app11156779

Academic Editor: Ioana Chiulan

Received: 23 June 2021

Accepted: 21 July 2021

Published: 23 July 2021

Publisher's Note: MDPI stays neutral with regard to jurisdictional claims in published maps and institutional affiliations.

Copyright: (C) 2021 by the authors. Licensee MDPI, Basel, Switzerland. This article is an open access article distributed under the terms and conditions of the Creative Commons Attribution (CC BY) license (https:/ / creativecommons.org/licenses/by/ $4.0 /)$.
Featured Application: The work described in this paper has significant potential for medical applications. As an example, these peptides can be incorporated into wound dressings to treat chronic wounds, increasing their re-epithelization, or to treat other skin diseases, such as psoriasis.

Abstract: FAO estimates that in 2030 the poultry meat production could reach 120 million tons, which is a challenge in terms of waste management. Feathers are mainly composed of keratin, an important biomaterial. Using feathers as a source of keratin will minimize the waste generated, while contributing to supply an important material for several industries, such as pharmaceutical and biomedical. The peptides were extracted from the feathers by microbial degradation. In this study, we evaluated the peptides effect on keratinocyte metabolic activity and migration. The influence of these peptides on non-activated and activated macrophages was also assessed. It was demonstrated that depending on the keratin peptide fraction in contact with keratinocytes, it is possible to modulate the migration rate of the keratinocytes. Peptide fraction with low molecular weight increases migration, while peptides with a high range of molecular sizes decreases it. Some peptide fractions induce the secretion of TNF- $\alpha$ in non-activated macrophages and not on activated macrophages, demonstrating that these peptides should only be placed in contact with cells, in the context of an ongoing inflammatory process. This work is a step forward on the understanding of keratin peptides influence on keratinocytes and immune cells system cells, macrophages.

Keywords: chicken feathers; microbial hydrolysis; keratin peptides; keratinocytes; cellular migration; inflammation

\section{Introduction}

The Food and Agriculture Organization estimates that in 2030 the poultry meat production could reach 120 million tons [1,2]. This fact poses a huge challenge in terms of waste management. Worldwide, it is calculated that the poultry-processing industry generates over 5 million tons of feather biomass [3]. This represents a serious waste hazard since only a small amount is processed into valuable products, such as feather meal or fertilisers [4]. Due to economic and environmental pressures, the industry is forced to find better ways to deal with feathers waste and generate economic value. This is particularly important due to the EU Directive 1999/31/EC on the landfill of waste [5], which restricts the disposal of waste with a significant concentration of biodegradable materials and with 
high burning values, such as feathers. Finding an eco-friendly and effective way to reuse chicken feathers waste is of the utmost importance for this industry. The importance is not only due to the necessity to comply with the law and contribute to the 2030 United Nations goals [6] for sustainable development, but it is an opportunity to reduce costs in waste management. Furthermore, it is also an opportunity to create high-value products that can be used, for example, in the pharmaceutical and dermo-cosmetic industry. In this way, chicken feathers can be recycled and provide high-value materials, decreasing economic and environmental pressures [4]. The poultry industry could receive a boost based on renewable and sustainable growth.

The possibility to use feather waste material from the poultry industry in dermocosmetics is related to its high content $(90 \%)$ in a specific protein, keratin, particularly $\beta$-keratin. Keratin is a widely used material in the pharmaceutical, cosmetic, medical, biomedical, and biotechnological industries due to its unique characteristics of bioactivity, biodegradability, and biocompatibility [3,7].

Several techniques can be used to extract keratin from feathers, such as acid and alkali hydrolysis, hydrothermal methods, high-density steam flash explosion, and ionic liquids. These techniques raise even more environmental concerns and have a low keratin yield [8]. The use of enzymatic and microbial keratinases can overcome all these problems [9]. The use of keratinases involves a few steps, namely keratinases production by bacteria or fungi strains, followed by its isolation and purification. Then, keratinases can be incubated with a rich keratin-containing substrate that can be hydrolysed to soluble peptides without the loss of essential amino acids [10,11]. Enzymatic keratinolysis is an effective, economic, and environmentally friendly method to extract keratin-based peptides from chicken feathers.

For the past years', keratin-based biomaterials have gained interest due to keratin biodegradability, biocompatibility, and mechanical durability [12]. Keratin is particularly interesting for skin applications, as it is the most abundant structural protein in epithelial cells after collagen [13]. Psoriasis, chronic cutaneous wound, and skin cancer are common skin diseases associated with the dysregulation of keratinocyte proliferation [14]. This event is often linked with a pathological pathway of regenerative maturation characterized by a higher rate of proliferation, aberrant response to growth factors, faulty differentiation, and increased migratory capability [14]. Keratins are typical intermediate filament proteins, having an important role in the mechanical stability and integrity of epithelial cells and tissues [15]. These proteins are also involved in regulatory functions and intracellular signalling pathways, such as wound healing [15].

The interactions between keratins and skin cells have been studied for many years. At the beginning of the 1950s, Giroud and Leblond, and later in the 1970s, Sun et al. studied the intermolecular disulphide bond of keratins on keratinocytes and their influence on the final stage on cell differentiation [16,17]. This fact demonstrates the importance of keratin interactions. Moreover, it is known that actin cytoskeleton is crucial for motility of adult keratinocytes; there is evidence that keratins, which are normally basally restricted, appear suprabasally in keratinocytes at the wound margin [18]. It is also described that short filament keratins 6, keratin 16 and 17 are induced and appear to help retract other cellular keratins into juxtanuclear aggregates within the actively crawling cells $[18,19]$. These studies demonstrated the importance of keratin on wound healing, particularly migration.

The peptide molecular weight has a significant influence on the cellular metabolism, so on this work, keratin peptides obtained from microbial chicken-feather degradation were fractioned, according to their molecular weight, and their effect on keratinocyte migration and metabolic activity as well as on macrophage release of TNF- $\alpha$ was evaluated.

\section{Materials and Methods}

\subsection{Microorganisms}

The Bacillus subtilis (S188D) used in this study belong to the collection of Bacillus of the University of Azores (Portugal). This strain was chosen for this work due to its high capability to hydrolase chicken feathers (results obtained in previous tests, data not 
shown). A single fresh colony of strain S188D was grown in $5 \mathrm{~mL}$ of lysogeny broth (LB) $(10 \mathrm{~g} / \mathrm{L}$ tryptone, $5 \mathrm{~g} / \mathrm{L}$ yeast extract and $5 \mathrm{~g} / \mathrm{L} \mathrm{NaCl})$ at $28^{\circ} \mathrm{C}$ for $18 \mathrm{~h}$, for later use in the fermentation process.

\subsection{Fermentation}

Chicken feathers were thoroughly washed in current water, dried at $60^{\circ} \mathrm{C}$ for $24 \mathrm{~h}$ and shredded in a blade mill before fermentation. For microbial fermentation, $2 \mathrm{~g}$ of shredded chicken feathers were incubated with $100 \mathrm{~mL}$ of minimum medium $\left(1 \mathrm{~g}\left(\mathrm{NH}_{4}\right)_{2} \mathrm{SO}_{4}, 3 \mathrm{~g}\right.$ $\mathrm{KH}_{2} \mathrm{PO}_{4}, 0.1 \mathrm{~g} / \mathrm{L} \mathrm{MgSO}_{4} .7 \mathrm{H}_{2} \mathrm{O}, 7 \mathrm{~g} \mathrm{~K}_{2} \mathrm{HPO}_{4}$ and $0.2 \mathrm{~g}$ yeast extract per litre, $\mathrm{pH}$ 7) [20], and $2 \mathrm{~mL}$ of LB S188D culture ( $0.5 \mathrm{MacFarland}$ standard at $600 \mathrm{~nm}$ ) transferred to the medium with feathers. The fermentation was performed at $28{ }^{\circ} \mathrm{C}$ and $120 \mathrm{rpm}$ for $48 \mathrm{~h}$. These conditions of solid/liquid ratio, temperature, agitation, and time were previously optimized in our group (data not shown).

\subsection{Isolation, Purification and Fractionation}

At the end of the fermentation, bacteria and contaminant products were separated by centrifugation at $8000 \mathrm{~g}$ for $10 \mathrm{~min}$, using a fixed angle rotor (Megafuge, Heraeus). The supernatant was then filtered through a $0.22 \mu \mathrm{m}$ cellulose acetate membrane (Millipore) and concentrated by tangential flow filtration (TFF). The TFF was performed using a polyethersulfone cassette (Millipore) with $10 \mathrm{KDa}$ cut-off membranes to obtain the peptides (eluted fractions). The peptides were then subjected to different purification procedures. First, they were desalted using a C18 column and eluted with graded series of acetonitrile, $20 \%, 40 \%$ and $80 \%$. Each eluted fraction was fractionated using a Superdex peptide column to obtain different molecular weight chromatographic peaks, P1, P2, P3, P4, and P5. The peptide was designated as P188D in accordance with the bacterial isolate used.

\subsection{Cells}

Human keratinocytes (NCTC 2544) were grown in Dulbecco's modified Eagle medium (DMEM; Lonza Group, Ltd., Braine l'Alleud, Belgium) with 10\% foetal bovine serum (FBS; Biosera, Ringmer, UK) and 1\% penicillin-streptomycin (complete medium). Cultures were maintained at $37^{\circ} \mathrm{C}$ in a humidified atmosphere of $5 \% \mathrm{CO}_{2}$.

Human dermal fibroblasts (Zen-Bio DF-F) were used in the preliminary viability assay (outsourced-Tebu-Bio). The cells were grown in Dulbecco's modified Eagle medium (DMEM; Lonza Group, Ltd., Braine l'Alleud, Belgium) with 10\% foetal bovine serum (FBS; Biosera, Ringmer, UK) and $1 \%$ penicillin-streptomycin (complete medium). Cultures were maintained at $37^{\circ} \mathrm{C}$ in a humidified atmosphere of $5 \% \mathrm{CO}_{2}$.

Macrophage cell line Raw 264.7 was also used to evaluate secretion of TNF- $\alpha$, proinflammatory cytokine, after incubation with the peptides. This cell line was routinely cultured with DMEM high glucose, supplemented with $10 \%$ heat-inactivated FBS and $10 \mathrm{mM}$ 4-(2-hydroxyethyl)1-piperazineethanesulfonic acid (HEPES) buffer in tissue culture flasks $5 \%(v / v) \mathrm{CO}_{2}$ at $37^{\circ} \mathrm{C}$.

\subsubsection{Proliferation Assay}

Keratinocytes were maintained with complete medium and seeded into 96-well plates $\left(2 \times 10^{4}\right.$ cells $\left./ \mathrm{mL}\right)$. The cells were incubated overnight at $37^{\circ} \mathrm{C}$ in $5 \% \mathrm{CO}_{2}$ atmosphere. After $24 \mathrm{~h}$, the culture medium was replaced by complete medium with $45 \mu \mathrm{g} / \mathrm{mL}$ of each peptide solution. Resazurin sodium salt was diluted in PBS to a concentration of $0.15 \mathrm{~g} / \mathrm{L}$ and filter $(0.2 \mu \mathrm{m}$ pore diameter). The resazurin working solution was prepared by diluting resazurin stock solutions 1:5 in complete medium. After $24 \mathrm{~h}$ of contact, the cells were washed with PBS and incubated with resazurin working solution for $2 \mathrm{~h}$. At this time point, the supernatant was removed and placed into black, opaque 96-well plates to measure the conversion of rezaruin to resorfin. For that, a fluorimeter with an excitation wavelength at $540 \mathrm{~nm}$ and emission at $590 \mathrm{~nm}$ was used. 


\subsubsection{Migration Assay}

Keratinocytes were seeded into a six-well plate $\left(5 \times 10^{5}\right.$ cells $\left./ \mathrm{mL}\right)$ and incubated overnight at $37^{\circ} \mathrm{C}$ in $5 \% \mathrm{CO} 2$ atmosphere. A scratch on the confluent cell layer was performed with a pipette tip. The culture medium was then replaced by complete medium and $45 \mu \mathrm{g} / \mathrm{mL}$ of each keratin peptides solution. Cell migration was monitored microscopically, and images were acquired at $0 \mathrm{~h}, 6 \mathrm{~h}$ and $24 \mathrm{~h}$, in the same region.

The area of the scratch was measured at different time points using Image J's plugin, MRI Wound Healing Tool.

\subsubsection{Quantification of TNF- $\alpha$}

The macrophage cell line Raw 264.7 was routinely cultured in DMEM supplemented with $10 \%$ heat-inactivated foetal calf serum, $2 \mathrm{mM}$ glutamine, $1 \mathrm{mM}$ sodium pyruvate, and $25 \mathrm{mM}$ HEPES buffer, in tissue culture flasks (Nagle Nunc, Int., Hereford, UK) in a humified atmosphere with $5 \%(v / v) \mathrm{CO}_{2}$ at $37^{\circ} \mathrm{C}$ (Binder CB150; Tuttlingen, Germany).

After confluent growth, macrophage cells were washed with fresh medium and recovered by scrapping. Viable cells were counted by Trypan blue exclusion in the haemocytometer and resuspended in DMEM to a final concentration of $1 \times 10^{5}$ cells $/ \mathrm{mL}$. Then, $500 \mu \mathrm{L}$ of the macrophage suspension was cultured in 24-well tissue culture plates. Cells were incubated overnight with increasing lipopolysaccharide (LPS) concentrations $(0.08,0.33$, and $1 \mu \mathrm{g} / \mathrm{mL}$ ). After incubation, supernatants were collected, and the cells were treated with different peptide fractions. Then, $24 \mathrm{~h}$ after treatment the cells' supernatants were stored at $-20^{\circ} \mathrm{C}$ for TNF- $\alpha$ quantification. The Mouse TNF alpha Elisa Ready-SET-Go ${ }^{\circledR}$ (Sensitivity: $8 \mathrm{pg} / \mathrm{mL}$ ) was used according to the manufacturer's instructions (Affymetrix, eBioscience). Cells incubated only with DMEM were considered negative controls. Two other controls were also performed: cells treated only with peptides and cells treated with different concentrations of LPS.

\subsection{Mass Spectrometry Analysis and Peptide/Protein Identification}

Mass spectrometry was performed at the UniMS—Mass Spectrometry Unit, ITQB/IBET, Oeiras, Portugal. Briefly, $20 \mu \mathrm{L}$ of the samples were and diluted $1: 20$ in buffer A $(0.1 \%$ formic acid in water, Fisher Chemicals, Geel, Belgium).

Liquid chromatography-tandem mass spectrometry (LC-MS/MS) analysis was performed on an ekspert ${ }^{\mathrm{TM}}$ NanoLC $425 \mathrm{cHiPLC}^{\circledR}$ system coupled with a TripleTOF ${ }^{\circledR} 6600$ with a DuoSpray Turbo V ion source (Sciex, Framingham, MA, USA). Peptides were separated through reversed-phase chromatography (RP-LC). Separation was performed at $1 \mu \mathrm{L} / \mathrm{min}$, on a HALO C18 column (Sciex $0.5 \times 50 \mathrm{~mm}, 2.7 \mu \mathrm{m}, 90 \AA$ ). The gradient was as follows: 0-1 min, 5\% B (0.1\% formic acid in acetonitrile, Fisher Chemicals, Geel, Belgium); 1-31 min, 5-30\% B; 31-34 min, 30-95\% B; 34-36 min, 95\% B; 36-38 min, 95-5\% B; 38-42 min, 5\% B.

Peptides were sprayed into the MS through an ESI electrode (50 $\mu \mathrm{m}$, Eksigent). The source parameters were set as follows: $20 \mathrm{GS} 1,0 \mathrm{GS} 2,30 \mathrm{CUR}, 5.5 \mathrm{keV}$ ISVF and $100{ }^{\circ} \mathrm{C}$ IHT. An information-dependent acquisition (IDA) method was set with a TOF-MS survey scan of $400-2000 \mathrm{~m} / \mathrm{z}$. The 40 most intense precursors were selected for subsequent fragmentation and the MS/MS were acquired in high-sensitivity mode. The obtained spectra were processed and analysed using ProteinPilot ${ }^{\mathrm{TM}}$ software, with the Paragon search engine (version 5.0, Sciex). A database containing the sequences of the proteins of interest was used (Gallus gallus feather keratin, from Uniprot 09-2017). The instrument selected was TripleTOF 6600. The ID focus was on biological modifications and amino acid substitutions. The search effort was set as thorough. Only the proteins with an unused protein score above 2.2 and $99 \%$ confidence were considered.

\subsection{Statistical Analysis}

All measurements were performed in triplicate and data presented as mean. For the selected evaluation tests, the means of all tested formulations were compared with 
each other by means of one paired Student's $t$-test or one-way ANOVA. The statistical significance level $(p)$ was set at $<0.05$.

\section{Results and Discussion}

\subsection{Cell Metabolic Activity and Migration}

Cellular migration is of the utmost importance for several mechanisms, such as immune response, wound repair and tissue homeostasis [21]. On the other hand, an aberrant cell migration leads to several pathologies such as the invasion of malignant cells into the surrounding tissue, with the formation of tumour metastasis, leading to a poorer prognostic for the patient [22].

A patient with a chronic wound has a compromised quality of life due to excruciating pain and the constant need for medical care, resulting in a significant burden to the health system worldwide. Briefly, the physiological process of wound healing has several steps, such as haemostasis, inflammation, proliferation, and remodelling. The haemostasis starts as soon as the injury occurs and is characterized by vasoconstriction and blood clotting. This stage is of the utmost importance as it prevents excessive blood loss and provides the required matrix for cell migration. Upon the inflammation stage in which phagocytic cells are recruited, the proliferation stage starts. At this stage, several growth factors and cytokines are recruited by different cell types, such as keratinocytes. The final stage is characterized by the formation and organization of collagen bundles [21]. If an arrest or delay occurs in any of these stages, particularly in the inflammation stage, it can lead to the formation of a chronic wound. It is known that keratinocytes have an important role in wound healing, particularly in re-epithelization [23]. The non-migration of these cells to the injury site is associated with the clinical phenotype of chronic wounds.

Even though keratinocytes are not motile in normal steady-state condition, in the presence of signalling molecules, they can migrate to re-epithelize the wound site [24]. Consequently, the enhancement of the keratinocyte migration rate is of the utmost importance for wound re-epithelization, particularly in the case of chronic wounds [25].

On the other hand, cancer metastization or invasion into the surrounding tissue leads to a poorer prognostic for the patient, as in the case of invasive squamous cell carcinoma [22]. Squamous cell carcinoma and basal cell carcinoma are keratinocyte carcinomas, particularly diagnosed in fair-skinned populations [26,27]. The decrease in cell migration might result in a less invasive tumour.

The ability of keratinocytes to migrate from one edge of the scratch, performed on a cell confluent monolayer, to its opposite edge was evaluated for a period of $24 \mathrm{~h}$, in the presence and absence of the peptides designated by P188D. First, a preliminary cell viability study using fibroblasts demonstrated that the presence of 25 and $50 \mu \mathrm{g} / \mathrm{mL}$ of peptides resulted in $94.2 \pm 0.77$ and $92.4 \pm 1.55 \%$ of viable cells, respectively. Therefore, $45 \mu \mathrm{g} / \mathrm{mL}$ was the chosen concentration for the following tests.

The effect of P188D peptide on keratinocyte migration was evaluated up to $24 \mathrm{~h}$ hours of contact. The presence of the peptide seems to decrease the keratinocyte migration rate in comparison to the control, this effect being clear at $24 \mathrm{~h}$ of contact (Figure 1). Thus, it seems that the presence of the peptides negatively affects keratinocyte migration, which could be important to reduce the invasiveness of skin cancer cells.

The microbial degradation of a protein results in several peptides with different sizes, amino acid composition and sequence. It is known that these characteristics have a striking effect on several physiologic mechanisms [28]. Therefore, to better understand the effect observed on keratinocyte migration, peptides were fractioned into smaller fractions using different percentages of acetonitrile $20 \%, 40 \%$ and $80 \%(20 \%, 40 \%$ and $80 \%$ fraction peptide). The final result was a solution with a narrowed peptides distribution. The influence of these fractions on the keratinocyte metabolic activity and migration was once again evaluated. 

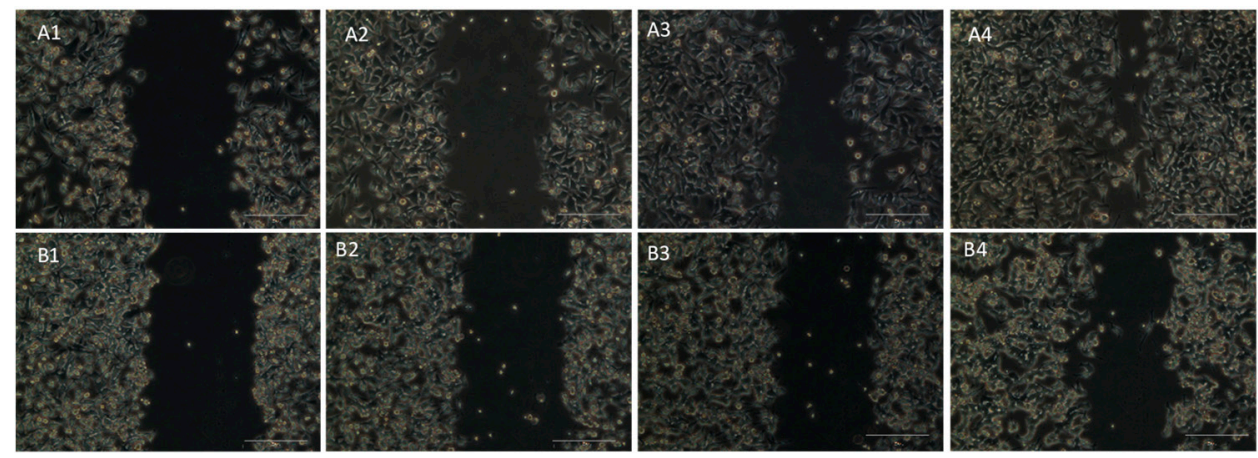

Figure 1. Keratinocyte migration in absence (A) and presence (B) of P188D peptide over time. 1 -before contact, $2-2 \mathrm{~h}, 3-6 \mathrm{~h}, 4-24 \mathrm{~h}$, respectively. Scale bar-200 $\mathrm{mm}$.

As can be seen in Figure 2A,B, the presence of the $20 \%$ peptide fraction decreased the metabolic activity and migration rate of the keratinocytes, although it did not reach statistical significance. On the other hand, fractions 40 and $80 \%$ do not seem to have any effect on either mechanism. As these fractions did not induce significant changes in the keratinocyte proliferation and migration rate, an additional fractionation was performed, where peptides were separated according to their molecular weight, ranging from 9090 to $401 \mathrm{Da}$ for the $20 \%$ fraction (P188D 20\%) and from 8082 to $382 \mathrm{Da}$ for the $40 \%$ fraction (P188D 40\%) (Table 1). Once again, the keratinocyte proliferation and migration rate were determined in contact with these new peptide fractions.
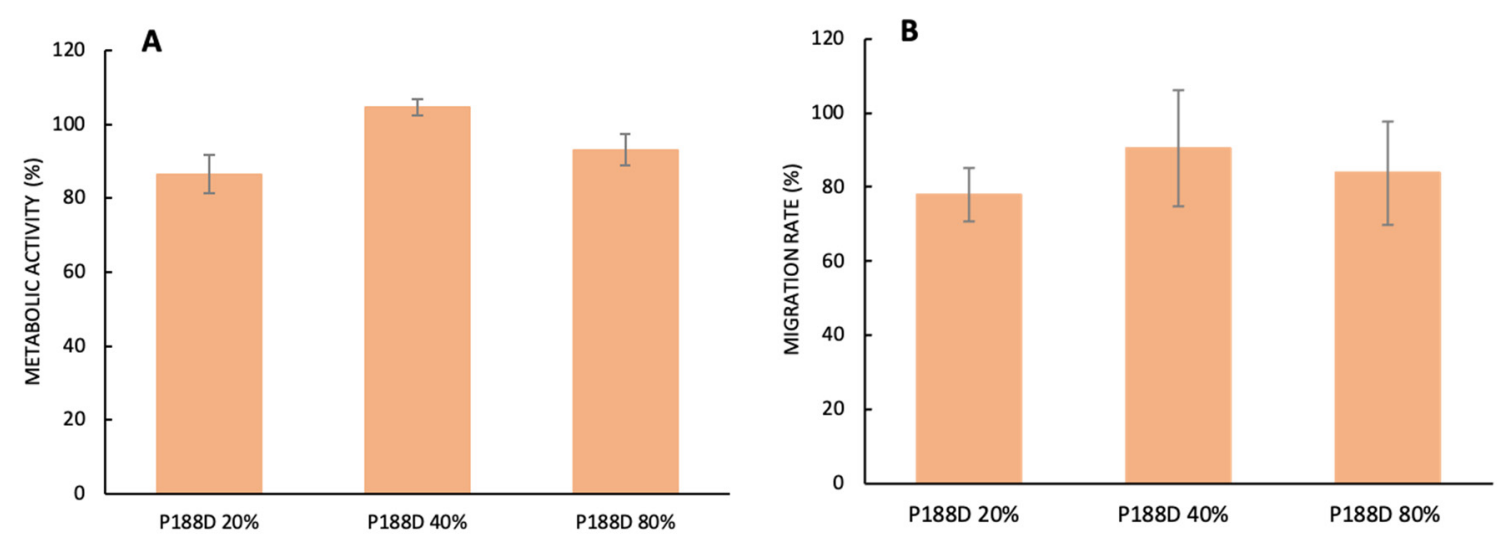

Figure 2. Keratinocyte proliferation (A) and migration rate (B) (in comparison to the control) in the presence of peptide fractions $(45 \mathrm{~g} / \mathrm{mL})$.

Table 1. Peptide fractions and respective molecular weight.

\begin{tabular}{ccc}
\hline Peptide Fraction. & Chromatographic Peak & Molecular Weight (Da) \\
\hline \multirow{3}{*}{ P188D 20\% } & P1 & 9090 \\
& P2 & 1361 \\
& P3 & 401 \\
\hline & P1 & 8082 \\
P188D 40\% & P2 & 4699 \\
& P3 & 2473 \\
P4 & 1199 \\
& P5 & 382 \\
\hline
\end{tabular}

In this analysis, the results obtained were very distinct (Figure 3) from the previous one (fraction $20 \%, 40 \%$ and $80 \%$ ). Significant changes were observed in the metabolic activity of cells in the presence of peptides, particularly in the presence of $40 \%$ fraction 
peptides. Analysing Figure 3A, it is clear that fractions P188D 20\% P1, P188D 40\% P1 seem to induce a higher metabolic activity of these cells; in contrast, P188D 40\% P3 induced a decrease in the metabolic activity. Even though the results showed that sub-fraction P1 from 20\% fraction peptide induced the highest metabolic activity in comparison to P2 or $\mathrm{P} 3$ from the same fraction, these differences did not reach statistical significance. On the other hand, significant changes were observed for the peptides from the $40 \%$ fraction, particularly P188D 40\% P1, P3 and P5. While P1 significantly increased the metabolic activity, P3 decreased it.
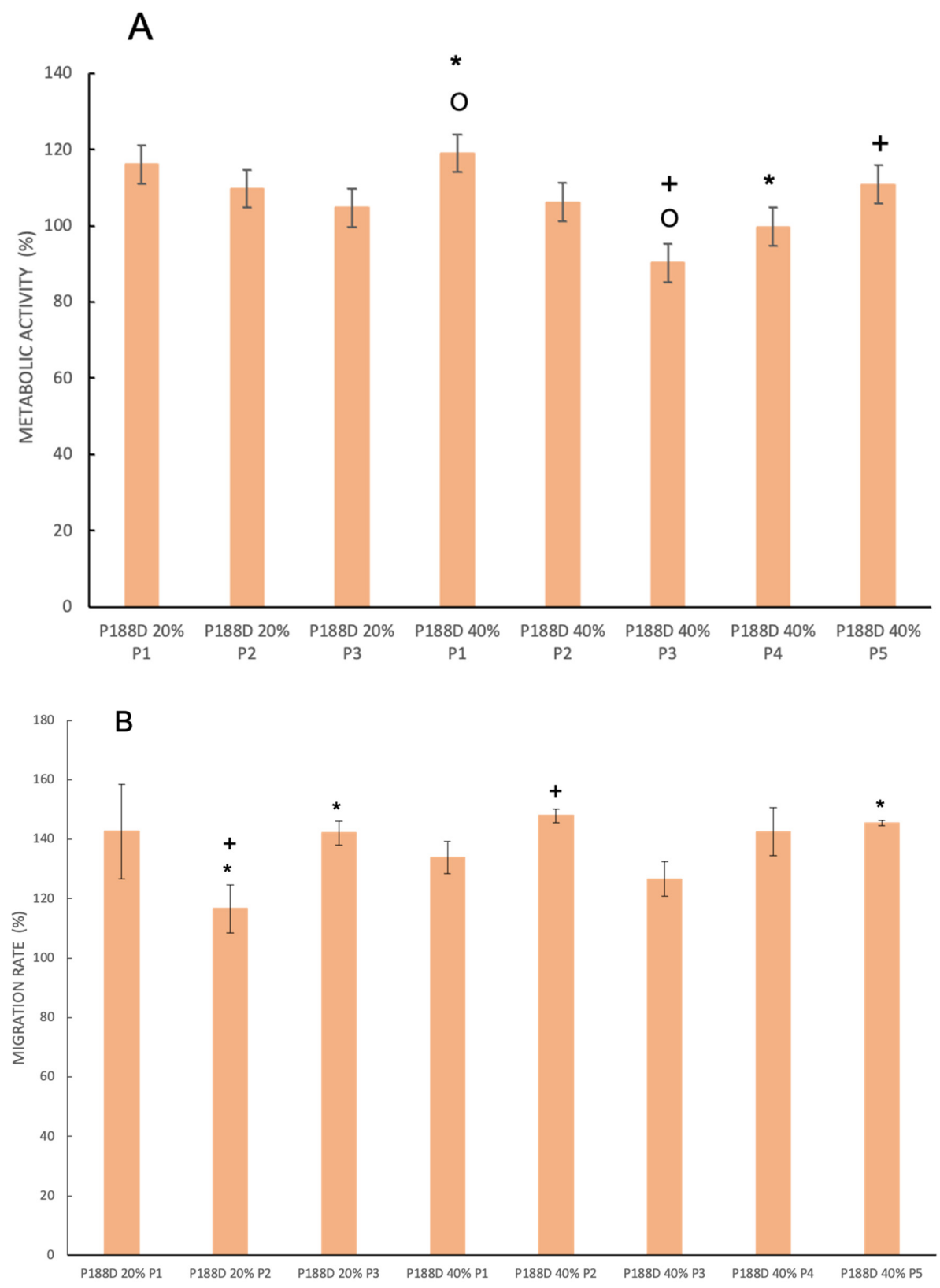

Figure 3. Keratinocyte metabolic activity (A) and keratinocyte migration rate (B) (in comparison to the control) in the presence of peptide fraction. Same symbol shows significant differences between groups $(p<0.05) .{ }^{*}$. + statistical significant between the groups.

All the peptide sub-fractions induced an increase in the keratinocyte migration rate (Figure 3B), with significant differences. P188D 20\%, P2 and P3 are significantly different, with the latter presenting a higher migration rate in comparison to the former. A similar 
result was observed for P188D 40\% P2, wherein P188D 20\% P2 and P188D 40\% P2 are significantly different, with the latter inducing a higher migration rate. P188D $40 \%$ P3 also significantly affects migration in comparison with P188D 20\% P1 and P188D $20 \%$ P3. It seems that the presence of these peptides has a more significant effect on the migratory ability of these cells than on their metabolic activity. In this case, the use of fractioned peptides is very important for skin reepithelization and therefore for the treatment of chronic wounds.

It is important to mention that resazurin assay is based on the capacity of living cells to transform resazurin to resorufin [29]. This ability is correlated with cell viability and cell number/proliferation. The basis for this understanding is that the higher the conversion of the dye, the higher the cell number. Therefore, taking into consideration this fact, it is possible to interpret the results observed, as the peptides fraction has a higher influence on cellular migration than on proliferation.

There are different physiological or pathological conditions, such as wound repair that induce cells to shift their phenotype from proliferative to migratory in response to similar stimulus (reciprocal control of cell proliferation and migration). It is known that cytokines produced by cells present at the wound area can act as a chemoattractant for distant cells, leading to cell migration [30]. However, upon their arrival, the cells switch from a migrating phenotype to a proliferating one [30]. In this case, the wound inflicted on the cell monolayer may have induced cells to release chemoattractant, signalling cells to migrate to the injury site.

It has been demonstrated that keratin intermediate filaments regulate proliferation, migration, adhesion, and inflammatory phenotype of keratinocytes [31].

Keratins 6,16 and 17 are very important as they are considered barrier alarmins, rapidly inducing keratinocytes to migrate to the injury site [31]. As in the wound healing process, keratinocytes suffer dramatic changes as they are required to migrate and proliferate during the healing phase. Their expression is founded in the epithelial remodelling phase until the barrier function is repaired, demonstrating the importance of these keratins in wound repair [31]. Among others, the expression of keratin 6, 16, and 17 persist through the epithelial remodelling phase until the barrier function is restored [32]. It is hypothesized that the peptides in the study may have a similar role to these keratins.

\subsection{Quantification of TNF- $\alpha$}

Inflammation is a crucial process in several medical conditions, such as psoriasis and wound healing; therefore, the ability of these peptide fractions to influence the inflammatory response in terms of TNF- $\alpha$ release by macrophages was evaluated.

This assay had two distinct steps; the first one was to evaluate if the peptide fractions induced an inflammatory response in non-activated macrophages ( $0 \mathrm{mg} / \mathrm{mL}$ of LPS) and the second one was to evaluate if, in LPS pre-activated macrophages, the peptides would influence the release of the pro-inflammatory cytokine.

As it can be seen in Figure $4 \mathrm{~A}$ in non-activated macrophages, the peptide fraction P188D 40\% induces a significantly high release of TNF- $\alpha$ in comparison to the control (cell culture media only), while the increase in TNF- $\alpha$ in the presence of P188D 20\% is significantly lower and similar to the control (no statistically significant difference). In the presence of LPS pre-activated macrophages, the levels of TNF- $\alpha$ with or without the peptides fraction is similar. However, the amount of TNF- $\alpha$ released by peptide fraction P188D 40\% was significantly reduced in the presence of LPS. As it is known, the maintenance of an inflammatory microenvironment favours tumorigenesis, particularly in skin cancers, such as the squamous cell carcinoma and basal cell carcinoma, in which there is an important inflammatory component [33]. Even though these peptides are not able to decrease TNF- $\alpha$ release, they do not enhance it. This cytokine is important in the induction of a pro-inflammatory response and it seems that in activated macrophages the presence of these peptides will not contribute to enhancing inflammation, as in some of the traditional chemotherapy agents, such as cisplatin, paclitaxel, 5-fluorouracil, and doxorubicin [34]. 
Therefore, the use of these peptides, such as 20\% fraction peptides (P188D 20\%), which seems to decrease the migration rate as well as the proliferation rate, can be an interesting alternative to the traditional chemotherapy agents.

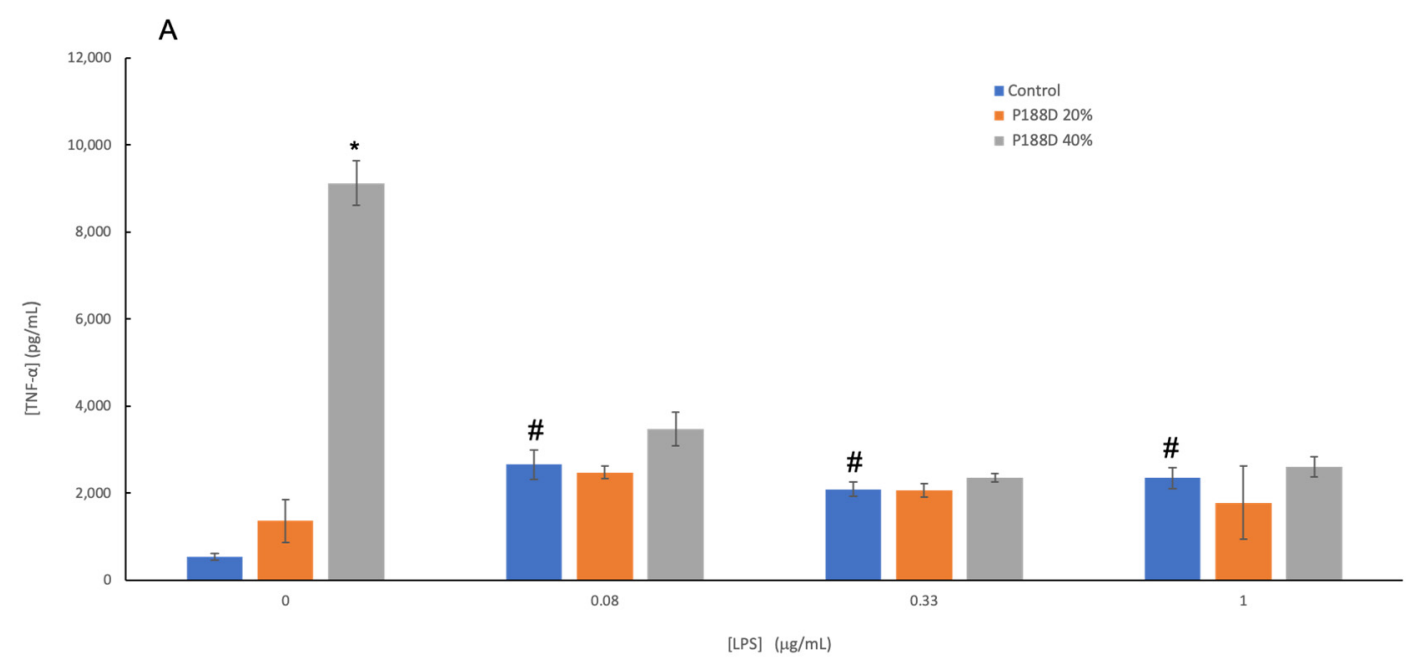

B

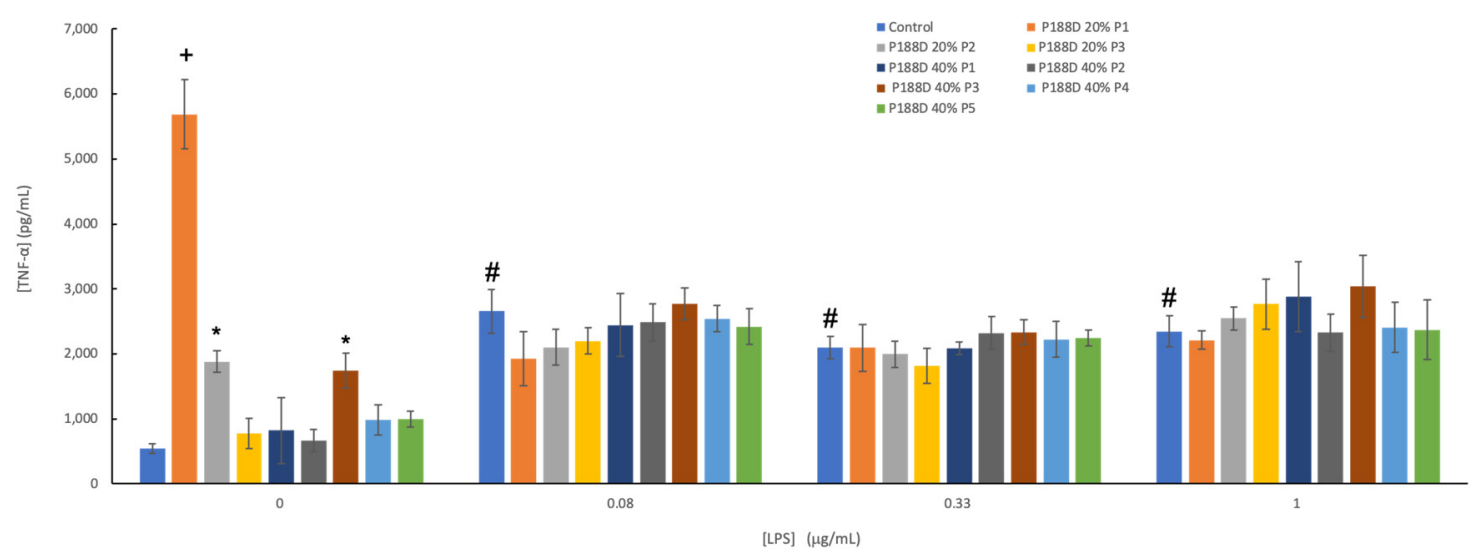

Figure 4. TNF- $\alpha$ release in the presence of the different fractions of the peptide (A) $20 \%$ and $40 \%$ fraction and (B) $20 \%$ P1, P2, P3 and 40\% P1, P2 and P3, P4, P5 in the presence of different concentrations of LPS. * shows statistical difference in comparison to the control and ${ }^{+}$shows statistical difference in comparison to all other conditions. \# shows statistical difference in comparison to the control of $0 \mathrm{mg} / \mathrm{mL}$ LPS $(p<0.05)$. The error bars represent the standard error.

The fractioned peptides from the last fractionation stage (chromatographic peaks by molecular weight) have a similar behaviour when in contact with pre-activated macrophages, where the values of this cytokine can be slightly higher than the negative control (DMEM) but never reaching statistical significance (Figure 4B). On the other hand, the contact of the different fractions with the non-activated macrophages (without LPS) induced distinct results. The P188D 20\% P1 and P2, and P188D 40\% P3 induced a significantly higher release of TNF- $\alpha$ in comparison to the negative control and all other conditions. Again, these results suggest that these peptides can be used in medical conditions, where there is an inflammatory process involved, as they will not aggravate it, as in the case of cancer or wound healing. These peptides open the possibility to modulate the migration rate of the keratinocytes involved in both processes, to enhance or decrease it, depending on the patient's needs. 
Gao et al. [35] demonstrated that the presence of hair keratins in a culture with rat neuronal Schwann cells increased proliferation and increased the number of cells passing through a trans-well pore. In the wound-healing experiment with primary Schwann cells, the damaged areas in the keratin group significantly decreased [35]. The presence of keratins from chicken feathers, when fractioned, also resulted in an increase in the metabolic activity/proliferation, with the exception of one fraction P188D 40\% P3. Our results also demonstrated that the peptide fraction stimulates cell proliferation in a wound-healing model similar to the one reported by Gao et al. [35]. However, the keratins extracted from the chicken feathers did not seem to significantly affect the production of the inflammatory cytokine TNF- $\alpha$, as described by Gao et al. [35]. This difference may be due to the different experimental settings; while in the Gao et al. [35] experimental model the keratin peptides are in contact with the cells prior to LPS activation, in our experimental model, the keratin peptides were added to the cell culture medium after LPS stimulation. Our experimental model allows the evaluation of these peptides as coadjutant molecules for the treatment of skin inflammatory diseases.

The current knowledge regarding macrophage activation in wound healing is the ability of these cells to shift from an M1 classical pro-inflammatory response (stimulated by TNF- $\alpha$, LPS as an example) to an M2 (polarized by IL-4, for example) anti-inflammatory response activation pathway after microbial infection control [36-38]. It has been described that a biomaterial made from human hair keratins elicit anti-inflammatory responses from naïve macrophages and polarize them towards M2 phenotype [38]. Waters et al. [39] described that keratin influences macrophage behaviour, although the mechanism behind it is extremely complex. Nevertheless, Waters et al. [39] describes that, macrophages are altered when in contact with an immobilized keratin biomaterial surface, and that these changes appear to trend toward an anti-inflammatory phenotype. Even more importantly, it is described that the response of macrophages is dependent on keratin molecular weight. This fact is very important as it can explain the differences observed on the response of the macrophages to the chicken feather keratin hydrolysate.

As the results differ depending on the peptide fraction present, a proteomic study was performed to evaluate the main sequences of peptides present in the solution, as well as comparing it to the keratin structure present in chicken feathers.

\subsection{Proteomics}

In order to identify an amino-acid sequence that could be responsible for the results observed, the different fractions were analysed using the ProteinPilot ${ }^{\mathrm{TM}}$ software and a database containing the sequences of the proteins of interest (Gallus gallus feather keratins, from Uniprot 09-2017). Peptide fractions of three proteins were detected, as described in Table 2.

Table 2. Peptide sequence of chicken feather keratin 1, 3 and 4 .

\begin{tabular}{cc}
\hline Feather Keratin $\mathbf{1}$ \\
\hline SCYDLCRPSAPTPLANSCNEPCVRQCQDSRVVIQPSPVVVTLPGPILSSFPQNTAVGSSTSAAVGSILSEEGVPISSGGFGISGLGSRFSSRRCLPY \\
\hline Feather Keratin 3 \\
\hline SCYDDLCRPCGPTPLANSCNEACVRQCQDSRVVIQPSPVVVTLPGPILSSFPQNTLVGSSTSAAVGSILSEEGVPISSGGFGISGLGSRFSGRRCLPC \\
Feather Keratin 4 \\
\hline
\end{tabular}

The proteomics analysis revealed the presence of peptides with different sequences and with homology to three distinct chicken keratin proteins: keratin 1,3 and 4, as described in Tables 3-6. 
Table 3. Peptide sequence of the chicken feather microbial degradation present in the fraction P188D $20 \%$ with $99 \%$ of confidence and its homology to chicken feather keratin 3 and 4.

\begin{tabular}{|c|c|c|c|}
\hline Protein & Sequence & Modifications & Number of Repeats \\
\hline 4 & SSFPQNTAVGS & & 2 \\
\hline 4 & SFPQNTAVGSSTSA & & 2 \\
\hline 4 & SFPQNTAVGSSTS & & \\
\hline 4 & GPILSSFPQNTAVGSSTS & & \\
\hline 4 & GPILSSFPQNTAVGSSTS & Deamidated(N)@10 & \\
\hline 4 & GPILSSFPQNTAVGSS & & \\
\hline 4 & GPILSSFPQNTAVGS & & 2 \\
\hline 4 & GPILSSFPQNTAVGS & Pro $\rightarrow$ Asn@8 & \\
\hline 4 & GPILSSFPQNTAVGS & Asn $\rightarrow$ His@10 & 4 \\
\hline 4 & GPILSSFPQNTAVGS & Deamidated(N)@10 & \\
\hline 4 & GPILSSFPQNTAVGS & Asn $\rightarrow$ His@10 & \\
\hline 4 & GPILSSFPQNTAVGS & Deamidated(N)@10 & 3 \\
\hline 4 & GPILSSFPQNTAVGS & Oxidation(P)@8, Gln $\rightarrow$ His@9 & \\
\hline 4 & GPILSSFPQNTAVG & Deamidated(N)@10 & \\
\hline 4 & GPILSSFPQNTAV & & \\
\hline 4 & GPILSSFPQNTAV & Deamidated(N)@10 & 3 \\
\hline 4 & GPILSSFPQNTAV & Asn $\rightarrow$ His@10 & \\
\hline 4 & GPILSSFPQNTA & & \\
\hline 4 & GPILSSFPQNTA & Deamidated(N)@10 & \\
\hline 4 & AVGSSTSAAVGSIL & & \\
\hline 3 & GSRFSGRR & Arg $\rightarrow$ Ser@7 & 2 \\
\hline 3 & GPILSSFPQNTLVGS & $\begin{array}{l}\text { Deamidated(N)@10, } \\
\text { Leu } \rightarrow \text { Val@12 }\end{array}$ & \\
\hline 3 & GPILSSFPQNTLVGS & $\begin{array}{c}\text { Deamidated(N)@10, } \\
\text { Leu } \rightarrow \text { Val@12 } \\
\end{array}$ & \\
\hline 4,3 & VVVTLPGPILS & & 2 \\
\hline 4,3 & VVTLPGPILS & & 2 \\
\hline 4,3 & VVTLPGPILS & Ser $\rightarrow$ Thr@10 & \\
\hline 4,3 & VVTLPGPIL & & 2 \\
\hline 4,3 & VVIQPSPVVVT & & \\
\hline 4,3 & VVIQPSPVVV & Pro $\rightarrow$ Ser@7 & 3 \\
\hline 4,3 & VVIQPSPVVV & Oxidation(P)@5, Ser $\rightarrow$ Pro@6 & \\
\hline 4,3 & VVIQPSPVVV & & 4 \\
\hline 4,3 & VVIQPSPVVV & Val $\rightarrow$ Leu@1 & 2 \\
\hline 4,3 & VVIQPSPVVV & Ser $\rightarrow$ Ala@6 & 3 \\
\hline 4,3 & VVIQPSPVVV & $\begin{array}{c}\text { Carbamidomethyl@N-term, } \\
\text { Ser } \rightarrow \text { Pro@6 }\end{array}$ & \\
\hline 4,3 & VVIQPSPV & & 2 \\
\hline 4,3 & VVIQPSPV & Ser $\rightarrow$ Ala@6 & \\
\hline 4,3 & VIQPSPVVV & Ser $\rightarrow$ Ala@5 & \\
\hline 4,3 & VIQPSPVV & Ser $\rightarrow$ Ala@5 & \\
\hline 4,3 & TLPGPILSSFPQ & & 2 \\
\hline 4,3 & TLPGPILS & Ser $\rightarrow$ Thr@8 & \\
\hline 4,3 & TLPGPILS & Ser $\rightarrow$ Thr@8 & \\
\hline 4,3 & TLPGPILS & Leu $\rightarrow$ Phe@2 & \\
\hline 4,3 & SSGGFGISGLGSR & Delta:H(2)C(2)@N-term & \\
\hline
\end{tabular}


Table 3. Cont.

\begin{tabular}{|c|c|c|c|}
\hline Protein & Sequence & Modifications & Number of Repeats \\
\hline 4,3 & SRVVIQPSP & & 2 \\
\hline 4,3 & SPVVVTLPGPILSSFPQN & Pro $\rightarrow$ Thr@8 & \\
\hline 4,3 & SPVVVTLPGPILSSFPQ & Pro $\rightarrow$ Thr@8 & \\
\hline 4,3 & SPVVVTLPGPILSSFPQ & Pro $\rightarrow$ Asp@8 & \\
\hline 4,3 & SPVVVTLPGPILSSFPQ & $\begin{array}{c}\text { Pro } \rightarrow \text { Asp@8, } \\
\text { Deamidated(Q)@17 }\end{array}$ & \\
\hline 4,3 & SPVVVTLPGPILSSFPQ & Oxidation(P)@8 & \\
\hline 4,3 & SPVVVTLPGPILS & & \\
\hline 4,3 & SPVVVTLPGPIL & & 2 \\
\hline 4,3 & SPVVVTLPGP & & 2 \\
\hline 4,3 & SPVVVTLPG & $\begin{array}{l}\text { Oxidation(P)@8, Gly } \rightarrow \text { Cys@9, } \\
\text { Carbamidomethyl(C)@9 }\end{array}$ & \\
\hline 4,3 & SPVVVTLP & & \\
\hline 4,3 & SGGFGISGLGSR & & \\
\hline 4,3 & SGGFGISGLGSR & Ile $\rightarrow$ Asn@6 & \\
\hline 4,3 & SEEGVPISSGGFGIS & Glu $\rightarrow$ Ser@3 & \\
\hline 4,3 & SEEGVPISSGGFGIS & & \\
\hline 4,3 & SEEGVPISSGGFGI & Glu $\rightarrow$ Ser@3 & 2 \\
\hline 4,3 & SEEGVPISSGGFGI & Glu $\rightarrow$ Ser@2 & \\
\hline 4,3 & SEEGVPISSGGF & Glu $\rightarrow$ Ser@3 & \\
\hline 4,3 & RVVIQPSP & Arg $\rightarrow$ Asp@1 & \\
\hline 4,3 & QPSPVVVTLPGPIL & Gln $\rightarrow$ Met@1 & \\
\hline 4,3 & QDSRVVIQPSP & & 2 \\
\hline 4,3 & PSPVVVTLPGPILS & & \\
\hline 4,3 & PSPVVVTLPGPIL & & \\
\hline 4,3 & PSPVVVTLPGP & & \\
\hline 4,3 & PSPVVVTLP & Pro $\rightarrow$ Ala@1 & \\
\hline 4,3 & PSPVVVTLP & & 2 \\
\hline 4,3 & PISSGGFGISGLGS & Leu $\rightarrow$ Thr@12 & \\
\hline 4,3 & LPGPILSSFPQN & & \\
\hline 4,3 & LPGPILSSFPQ & & \\
\hline 4,3 & IQPSPVVVTLP & & \\
\hline 4,3 & IQPSPVVVTLP & Ser $\rightarrow$ Pro@4 & 2 \\
\hline 4,3 & IQPSPVVVT & Ser $\rightarrow$ Pro@4 & 2 \\
\hline 4,3 & IQPSPVVV & Ser $\rightarrow$ Pro@4 & 5 \\
\hline 4,3 & ILSSFPQN & & 2 \\
\hline 4,3 & GVPISSGGFGISGLGSR & & 2 \\
\hline 4,3 & GVPISSGGFGIS & & 5 \\
\hline 4,3 & GVPISSGGFGI & & 3 \\
\hline 4,3 & GVPISSGGFGI & Ile $\rightarrow$ Phe@11 & \\
\hline 4,3 & GVPISSGGFG & & \\
\hline 4,3 & GVPISSGGF & & 3 \\
\hline 4,3 & GVPISSGGF & PhosphoHexNAc(S)@6 & \\
\hline 4,3 & GPILSSFPQNT & & 3 \\
\hline 4,3 & GPILSSFPQNT & Deamidated(N)@10 & 2 \\
\hline 4,3 & GPILSSFPQNT & Asn $\rightarrow$ His@10 & \\
\hline
\end{tabular}


Table 3. Cont.

\begin{tabular}{|c|c|c|c|}
\hline Protein & Sequence & Modifications & Number of Repeats \\
\hline 4,3 & GPILSSFPQN & & 7 \\
\hline 4,3 & GPILSSFPQN & Asn $\rightarrow$ Gln@10 & 3 \\
\hline 4,3 & GPILSSFPQN & Asn $\rightarrow$ Ser@10 & 2 \\
\hline 4,3 & GPILSSFPQN & Deamidated(N)@10 & \\
\hline 4,3 & GPILSSFPQ & & 2 \\
\hline 4,3 & GPILSSFPQ & Ser $\rightarrow$ Thr@5 & 3 \\
\hline 4,3 & GPILSSFP & & 4 \\
\hline 4,3 & GISGLGSRFS & Phe $\rightarrow$ Leu@9 & \\
\hline 4,3 & GISGLGSRFS & & 3 \\
\hline 4,3 & GISGLGSRF & Phe $\rightarrow$ Tyr@9 & \\
\hline 4,3 & GISGLGSRF & Ser $\rightarrow$ Gly@7 & 2 \\
\hline 4,3 & GGFGISGLGSRF & & 2 \\
\hline 4,3 & GGFGISGLGSR & & \\
\hline 4,3 & GFGISGLGSRF & & \\
\hline 4,3 & GFGISGLGSR & & 2 \\
\hline 4,3 & GFGISGLGSR & Ser $\rightarrow$ Gly@9 & \\
\hline 4,3 & EGVPISSGGFGIS & & 3 \\
\hline 4,3 & EGVPISSGGFGI & & \\
\hline 4,3 & EGVPISSGGF & Glu $\rightarrow$ Ser@1 & \\
\hline 4,3 & EEGVPISSGGFGI & Glu $\rightarrow$ Ser@2 & \\
\hline
\end{tabular}

Table 4. Peptide sequence of the chicken feather microbial degradation present in the fraction P188D $40 \%$ with $99 \%$ of confidence and its homology to Keratin Chicken Feather 4 and 1.

\begin{tabular}{cccc}
\hline Protein & Sequence & Modifications & Number of Repeats \\
\hline 4 & VVVTLPGPILSSFPQN & Pro $\rightarrow$ Asp@6 & 4 \\
\hline 4 & VVVTLPGPILSSFPQN & & 7 \\
\hline 4 & VVVTLPGPILSSFPQ & & \\
\hline 4 & VVVTLPGPILSSFPQ & Pro $\rightarrow$ Asn@6 & \\
\hline 4 & VVVTLPGPILSSFP & cGMP + RMP-loss(S)@12 & \\
\hline 4 & VVVTLPGPILSS & & 31 \\
\hline 4 & VVVTLPGPILS & Ser $\rightarrow$ Thr@11 & 3 \\
\hline 4 & VVVTLPGPILS & Thr $\rightarrow$ Leu@4 & \\
\hline 4 & VVVTLPGPILS & Pro $\rightarrow$ Met@6 & \\
\hline 4 & VVVTLPGPILS & & 5 \\
\hline 4 & VVVTLPGPIL & & \\
\hline 4 & VVVTLPGPI & & \\
\hline 4 & VVTLPGPILSSFPQN & Leu $\rightarrow$ Phe@4 & \\
\hline 4 & VVTLPGPILSSFPQ & & \\
\hline 4 & VVTLPGPILSSFPQ & Leu $\rightarrow$ Phe@4 & \\
\hline 4 & VVTLPGPILSS & Ser $\rightarrow$ Val@11 & \\
\hline 4 & VVTLPGPILS & Ser $\rightarrow$ Thr@10 & \\
\hline 4 & VVTLPGPIL & & \\
\hline 4 & VVIQPSPVVVTLPGPILSSF & & \\
\hline 4 & VVIQPSPVVVTLPGPILSSFPQ & & \\
\hline 4 & VVIQPSPVVVTLPGPILSSF & cGMP + RMP-loss(S)@19 \\
\hline
\end{tabular}


Table 4. Cont.

\begin{tabular}{|c|c|c|c|}
\hline Protein & Sequence & Modifications & Number of Repeats \\
\hline 4 & VVIQPSPVVVTLPGPILS & Pro $\rightarrow$ Ser@7 & \\
\hline 4 & VVIQPSPVVVTLPGPILS & & 6 \\
\hline 4 & VVIQPSPVVVTLPGPILS & Val $\rightarrow$ Leu@1 & \\
\hline 4 & VVIQPSPVVVTLPGPILS & Ser $\rightarrow$ Ala@6 & \\
\hline 4 & VVIQPSPVVVTLPGPIL & & 2 \\
\hline 4 & VVIQPSPVVVTLPGP & Pro $\rightarrow$ Ala@5, Oxidation(P)@7 & \\
\hline 4 & VVIQPSPVVVTLPGP & Pro $\rightarrow$ Thr@7 & 2 \\
\hline 4 & VVIQPSPVVVTLP & Pro $\rightarrow$ Ser@7 & 2 \\
\hline 4 & VVIQPSPVVVTLP & Oxidation(P)@7, Thr $\rightarrow$ Pro@11 & 3 \\
\hline 4 & VVIQPSPVVVTLP & Ser $\rightarrow$ Pro@6, Oxidation(P)@7 & \\
\hline 4 & VVIQPSPVVVTLP & Pro $\rightarrow$ Ser@7 & \\
\hline 4 & VVIQPSPVVVTLP & & 7 \\
\hline 4 & VVIQPSPVVVTLP & Val $\rightarrow$ Leu@1 & \\
\hline 4 & VVIQPSPVVVTLP & Ser $\rightarrow$ Ala@6 & 3 \\
\hline 4 & VVIQPSPVVVTLP & Pro $\rightarrow$ Ser@5, Oxidation(P)@7 & \\
\hline 4 & VVIQPSPVVVTLP & Oxidation(P)@5, Pro $\rightarrow$ Ser@7 & \\
\hline 4 & VTLPGPILSSFPQN & & \\
\hline 4 & VTLPGPILSSFPQ & & 4 \\
\hline 4 & VTLPGPILSSFPQ & Leu $\rightarrow$ Phe@3 & 3 \\
\hline 4 & VIQPSPVVVTLP & Ser $\rightarrow$ Ala@5 & \\
\hline 4 & VIQPSPVVVTLP & Ser $\rightarrow$ Ala@5 & \\
\hline 4 & TLPGPILSSFPQN & & 2 \\
\hline 4 & TLPGPILSSFPQ & & 6 \\
\hline 4 & TLPGPILSSFPQ & Ser $\rightarrow$ Thr@8 & \\
\hline 4 & TLPGPILSSFPQ & Leu $\rightarrow$ Phe@2 & 5 \\
\hline 4 & TLPGPILS & Leu $\rightarrow$ Phe@2 & \\
\hline 4 & TLPGPILS & Leu $\rightarrow$ Phe@2 & \\
\hline 4 & TLPGPILS & Ser $\rightarrow$ Phe@8 & \\
\hline 4 & SRVVIQPSP & Arg $\rightarrow$ Asp@2 & \\
\hline 4 & SPVVVTLPGPILSSFPQN & Pro $\rightarrow$ Thr@8 & \\
\hline 4 & SPVVVTLPGPILSSFPQ & & 4 \\
\hline 4 & SPVVVTLPGPILS & & 5 \\
\hline 4 & SPVVVTLPGPILS & Dehydrated(T)@6 & \\
\hline 4 & SPVVVTLPGPIL & & 3 \\
\hline 4 & SPVVVTLPGP & & \\
\hline 4 & SPVVVTLPG & $\begin{array}{c}\text { Oxidation(P)@8, Gly } \rightarrow \text { Cys@9, } \\
\text { Carbamidomethyl(C)@9 }\end{array}$ & \\
\hline 4 & SGGFGISGLGSRF & & \\
\hline 4 & SCGGFGISGLGSR & Cys $\rightarrow$ Leu@2 & \\
\hline 4 & RVVIQPSPVVVTLPGPILS & & \\
\hline 4 & PVVVTLPGPILSSFPQ & Pro $\rightarrow$ Thr@1 & \\
\hline 4 & PVVVTLPGPILS & Pro $\rightarrow$ Thr@1 & \\
\hline 4 & PVVVTLPGPILS & Pro $\rightarrow$ Ser@1 & 2 \\
\hline 4 & PVVVTLPGPIL & Pro $\rightarrow$ Thr@1 & \\
\hline 4 & PVVVTLPGP & Pro $\rightarrow$ Ser@1 & \\
\hline
\end{tabular}


Table 4. Cont.

\begin{tabular}{|c|c|c|c|}
\hline Protein & Sequence & Modifications & Number of Repeats \\
\hline 4 & PVVVTLPGP & Pro $\rightarrow$ Thr@1 & 2 \\
\hline 4 & PSPVVVTLPGPILS & & 3 \\
\hline 4 & PSPVVVTLPGPIL & Pro $\rightarrow$ Ala@1 & \\
\hline 4 & PSPVVVTLPGPIL & & 3 \\
\hline 4 & PSPVVVTLPGP & & \\
\hline 4 & LPGPILSSFPQNTAVGS & Deamidated(N)@12 & \\
\hline 4 & LPGPILSSFPQ & Ile $\rightarrow$ Phe@5 & 3 \\
\hline 4 & LPGPILSSFPQ & Leu $\rightarrow$ Phe@1 & \\
\hline 4 & LPGPILSSFPQ & & 2 \\
\hline 4 & IQPSPVVVTLPGPILSSFPQ & Ser $\rightarrow$ Pro@4 & 5 \\
\hline 4 & IQPSPVVVTLPGPILS & & 3 \\
\hline 4 & IQPSPVVVTLPGPILS & Ser $\rightarrow$ Pro@4 & 5 \\
\hline 4 & IQPSPVVVTLPGPIL & Ser $\rightarrow$ Pro@4 & \\
\hline 4 & IQPSPVVVTLPGP & Ser $\rightarrow$ Pro@4 & 3 \\
\hline 4 & IQPSPVVVTLP & Ser $\rightarrow$ Ala@4 & \\
\hline 4 & IQPSPVVVTLP & Ser $\rightarrow$ Pro@4 & 5 \\
\hline 4 & GVPISSGGFGISGLGSR & & \\
\hline 4 & GVPISSGGFGISGL & & \\
\hline 4 & GVPISSGGFGIS & Ile $\rightarrow$ Phe@11 & \\
\hline 4 & GVPISSGGFGI & 2 & 2 \\
\hline 4 & GVPISSGGFGI & Ile $\rightarrow$ Phe@11 & \\
\hline 4 & GPILSSFPQNTAVGS & & \\
\hline 4 & GPILSSFPQNTAVGS & Asn $\rightarrow$ His@10 & 3 \\
\hline 4 & GPILSSFPQNTAVGS & Deamidated(N)@10 & 2 \\
\hline 4 & GPILSSFPQNTAVGS & $\begin{array}{c}\text { Deamidated(N)@10, } \\
\text { Ala } \rightarrow \text { Val@12 }\end{array}$ & 2 \\
\hline 4 & GPILSSFPQNTAV & Deamidated(N)@10 & 3 \\
\hline 4 & GPILSSFPQNT & & 2 \\
\hline 4 & GPILSSFPQNT & Deamidated(N)@10 & \\
\hline 4 & GPILSSFPQN & & 5 \\
\hline 4 & GPILSSFPQ & & \\
\hline 4 & GPILSSFPQ & Ser $\rightarrow$ Thr@6 & \\
\hline 4 & GPILSSFPQ & Ser $\rightarrow$ Thr@5 & 2 \\
\hline 4 & GGFGISGLGSRFS & & 2 \\
\hline 4 & GGFGISGLGSRF & & 3 \\
\hline 4 & GGFGISGLGSR & & 3 \\
\hline 4 & GFGISGLGSRFS & Phe $\rightarrow$ Leu@11 & \\
\hline 4 & GFGISGLGSR & & 2 \\
\hline 4 & FGISGLGSR & & \\
\hline 4 & EGVPISSGGFGIS & & \\
\hline
\end{tabular}


Table 5. Peptide sequence of the chicken feather microbial degradation present in the fraction P188D 20\% P1, P2 and P3 with 99\% of confidence and its homology to chicken feather keratin 4, 1, 3, respectively.

\begin{tabular}{|c|c|c|c|}
\hline Sequence & Modifications & Protein Modifications & $\begin{array}{l}\text { Number of } \\
\text { Repeats }\end{array}$ \\
\hline \multicolumn{4}{|c|}{ P188D 20\% P1 } \\
\hline \multicolumn{4}{|l|}{ EGVPISSGGF } \\
\hline \multicolumn{4}{|l|}{ EGVPISSGGFGI } \\
\hline \multicolumn{4}{|l|}{ EGVPISSGGFGIS } \\
\hline \multicolumn{4}{|l|}{ GPILSSFPQ } \\
\hline \multicolumn{4}{|l|}{ GPILSSFPQN } \\
\hline \multicolumn{4}{|l|}{ GPILSSFPQNT } \\
\hline GPILSSFPQNTAV & Deamidated(N)@10 & & \\
\hline \multicolumn{4}{|l|}{ GVPISSGGF } \\
\hline \multicolumn{4}{|l|}{ GVPISSGGFGI } \\
\hline \multicolumn{4}{|l|}{ GVPISSGGFGIS } \\
\hline \multicolumn{4}{|l|}{ IQPSPVVVTLP } \\
\hline \multicolumn{4}{|l|}{ IQPSPVVVTLPGPILS } \\
\hline \multicolumn{4}{|l|}{ PSPVVVTLPGP } \\
\hline \multicolumn{4}{|l|}{ PSPVVVTLPGPILS } \\
\hline QDSRVVIQP & Gln $\rightarrow$ pyro-Glu@N-term & & \\
\hline QDSRVVIQPSP & Gln $\rightarrow$ pyro-Glu@N-term & & \\
\hline SFPQNTAVGSSTS & Deamidated(N)@5 & & \\
\hline SFPQNTAVGSSTSA & Deamidated(N)@5 & & \\
\hline SFPQNTAVGSSTSAA & Deamidated(N)@5 & & \\
\hline \multicolumn{4}{|l|}{ SGGFGISGLGSR } \\
\hline \multicolumn{4}{|l|}{ SPVVVTLPGP } \\
\hline \multicolumn{4}{|l|}{ SPVVVTLPGPILS } \\
\hline \multicolumn{4}{|l|}{ TLPGPILSSFPQ } \\
\hline \multicolumn{4}{|l|}{ VPISSGGFGI } \\
\hline \multicolumn{4}{|l|}{ VPISSGGFGIS } \\
\hline \multicolumn{4}{|l|}{ VVIQPSPV } \\
\hline \multicolumn{4}{|l|}{ VVIQPSPVVV } \\
\hline \multicolumn{4}{|l|}{ VVIQPSPVVVTLPGPILS } \\
\hline \multicolumn{4}{|l|}{ VVTLPGPILS } \\
\hline \multicolumn{4}{|l|}{ VVVTLPGPIL } \\
\hline \multicolumn{4}{|l|}{ VVVTLPGPILS } \\
\hline GPILSSFPQNTAVGS & Asn $\rightarrow$ His@10 & Asn $\rightarrow$ His@54 & \\
\hline EEGVPISSGGFGI & Glu $\rightarrow$ Ser@2 & Glu $\rightarrow$ Ser@72 & \\
\hline SEEGVPISSGGF & Glu $\rightarrow$ Ser@2 & Glu $\rightarrow$ Ser@71 & \\
\hline SEEGVPISSGGFGI & Glu $\rightarrow$ Ser@2 & Glu $\rightarrow$ Ser@71 & \\
\hline SEEGVPISSGGFGIS & Glu $\rightarrow$ Ser@2 & Glu $\rightarrow$ Ser@71 & \\
\hline EEGVPISSGGF & Glu $\rightarrow$ Ser@2 & Glu $\rightarrow$ Ser@72 & \\
\hline
\end{tabular}


Table 5. Cont.

\begin{tabular}{|c|c|c|c|}
\hline Sequence & Modifications & Protein Modifications & $\begin{array}{c}\text { Number of } \\
\text { Repeats }\end{array}$ \\
\hline EEGVPISSGGFGIS & Glu $\rightarrow$ Ser@2 & Glu $\rightarrow$ Ser@72 & \\
\hline SFPQNTAVGS & Asn $\rightarrow$ His@5 & Asn $\rightarrow$ His@54 & \\
\hline SSFPQNTAVGS & Asn $\rightarrow$ His@6 & Asn $\rightarrow$ His@54 & \\
\hline VVIQPSPVVVTLP & Ser $\rightarrow$ Val@6 & Ser $\rightarrow$ Val@37 & \\
\hline PVVVTLPGP & Pro $\rightarrow$ Thr@1 & Pro $\rightarrow$ Thr@38 & \\
\hline PVVVTLPGPIL & Pro $\rightarrow$ Ser@1 & Pro $\rightarrow$ Ser@38 & \\
\hline PVVVTLPGPILS & Pro $\rightarrow$ Thr@1 & Pro $\rightarrow$ Thr@38 & \\
\hline IQPSPVVVT & Ser $\rightarrow$ Pro@4 & Ser $\rightarrow$ Pro@37 & \\
\hline VIQPSPVVVTLP & Pro $\rightarrow$ Thr@6 & Pro $\rightarrow$ Thr@38 & \\
\hline IQPSPVVV & Ser $\rightarrow$ Pro@4 & Ser $\rightarrow$ Pro@37 & \\
\hline RVVIQPSP & Arg $\rightarrow$ Thr@1 & Arg $\rightarrow$ Thr@31 & \\
\hline PSPVVVTLP & Thr $\rightarrow$ Leu@7 & Thr $\rightarrow$ Leu@42 & \\
\hline SEEGVPISS & PhosphoHexNAc(S)@8 & PhosphoHexNAc(S)@77 & \\
\hline VPISSGGF & PhosphoHexNAc(S)@5 & PhosphoHexNAc(S)@78 & \\
\hline SPVVVTLPG & $\begin{array}{c}\text { Oxidation }(\mathrm{P}) @ 8 ; \\
\text { Gly } \rightarrow \text { Cys@9; } \\
\text { Carbamidomethyl(C)@9 }\end{array}$ & $\begin{array}{l}\text { Oxidation(P)@44; } \\
\text { Gly } \rightarrow \text { Cys@45 }\end{array}$ & \\
\hline DSRVVIQPSP & $\begin{array}{c}\text { Asp } \rightarrow \text { Thr@1; } \\
\text { Deamidated(R)@3 }\end{array}$ & $\begin{array}{c}\text { Asp } \rightarrow \text { Thr@29; } \\
\text { Deamidated(R)@31 }\end{array}$ & \\
\hline EEGVPISSGGF & Glu $\rightarrow$ Ser@1 & Glu $\rightarrow$ Ser@71 & \\
\hline EEGVPISSGGFGI & Glu $\rightarrow$ Ser@1 & Glu $\rightarrow$ Ser@71 & 2 \\
\hline EEGVPISSGGFGI & Glu $\rightarrow$ Ser@2 & Glu $\rightarrow$ Ser@72 & \\
\hline EEGVPISSGGFGIS & Glu $\rightarrow$ Ser@1 & Glu $\rightarrow$ Ser@71 & \\
\hline \multicolumn{4}{|l|}{ EGVPISSGGFGI } \\
\hline EGVPISSGGFGIS & & & 2 \\
\hline GPILSSFPQ & & & 3 \\
\hline GPILSSFPQN & & & 3 \\
\hline GPILSSFPQNT & & & 3 \\
\hline GPILSSFPQNTAV & Deamidated(N)@10 & & \\
\hline GPILSSFPQNTAVGS & Deamidated(N)@10 & & 4 \\
\hline GPILSSFPQNTAVGS & Asn $\rightarrow$ His@10 & Asn $\rightarrow$ His@54 & 3 \\
\hline GVPISSGGF & & & 2 \\
\hline \multicolumn{4}{|l|}{ GVPISSGGFGI } \\
\hline GVPISSGGFGIS & & & 2 \\
\hline IQPSPVVV & Ser $\rightarrow$ Pro@4 & Ser $\rightarrow$ Pro@37 & \\
\hline IQPSPVVVT & Ser $\rightarrow$ Pro@4 & Ser $\rightarrow$ Pro@37 & \\
\hline IQPSPVVVTLP & Pro $\rightarrow$ Thr@3 & Pro $\rightarrow$ Thr@36 & \\
\hline IQPSPVVVTLP & Pro $\rightarrow$ Thr@5 & Pro $\rightarrow$ Thr@38 & \\
\hline IQPSPVVVTLP & Thr $\rightarrow$ Leu@9 & Thr $\rightarrow$ Leu@42 & \\
\hline IQPSPVVVTLP & Pro $\rightarrow$ Ser@3 & Pro $\rightarrow$ Ser@36 & \\
\hline IQPSPVVVTLP & Ser $\rightarrow$ Pro@4 & Ser $\rightarrow$ Pro@37 & \\
\hline
\end{tabular}


Table 5. Cont.

\begin{tabular}{|c|c|c|c|}
\hline Sequence & Modifications & Protein Modifications & $\begin{array}{c}\text { Number of } \\
\text { Repeats }\end{array}$ \\
\hline \multicolumn{4}{|l|}{ PSPVVVTLP } \\
\hline PVVVTLPGP & Pro $\rightarrow$ Ser@1 & Pro $\rightarrow$ Ser@38 & \\
\hline PVVVTLPGP & Pro $\rightarrow$ Thr@1 & Pro $\rightarrow$ Thr@38 & \\
\hline PVVVTLPGP & Pro $\rightarrow$ Ser@1 & Pro $\rightarrow$ Ser@38 & \\
\hline PVVVTLPGPIL & Pro $\rightarrow$ Ser@1 & Pro $\rightarrow$ Ser@38 & 2 \\
\hline PVVVTLPGPIL & Pro $\rightarrow$ Thr@1 & Pro $\rightarrow$ Thr@38 & 2 \\
\hline PVVVTLPGPILS & Pro $\rightarrow$ Thr@1 & Pro $\rightarrow$ Thr@38 & \\
\hline PVVVTLPGPILS & Pro $\rightarrow$ Ser@1 & Pro $\rightarrow$ Ser@38 & 2 \\
\hline RVVIQPSP & Arg $\rightarrow$ Asp@1 & Arg $\rightarrow$ Asp@31 & \\
\hline \multicolumn{4}{|l|}{ SEEGVPISS } \\
\hline SEEGVPISS & Cation:Na(E)@3 & & 2 \\
\hline SEEGVPISS & Glu $\rightarrow$ Ser@2 & Glu $\rightarrow$ Ser@71 & \\
\hline SEEGVPISS & Glu $\rightarrow$ Ser@3 & Glu $\rightarrow$ Ser@72 & \\
\hline SEEGVPISS & Glu $\rightarrow$ Ser@3 & Glu $\rightarrow$ Ser@72 & \\
\hline SEEGVPISS & Glu $\rightarrow$ Ser@2 & Glu $\rightarrow$ Ser@71 & \\
\hline SEEGVPISS & Glu $\rightarrow$ Lys@2 & Glu $\rightarrow$ Lys@71 & \\
\hline SEEGVPISS & PhosphoHexNAc(S)@8 & PhosphoHexNAc(S)@77 & \\
\hline SEEGVPISS & PhosphoHexNAc(S)@9 & PhosphoHexNAc(S)@78 & \\
\hline SEEGVPISSGGF & Glu $\rightarrow$ Ser@2 & Glu $\rightarrow$ Ser@71 & \\
\hline SEEGVPISSGGF & Glu $\rightarrow$ Lys@2 & Glu $\rightarrow$ Lys@71 & \\
\hline SEEGVPISSGGF & Glu $\rightarrow$ Ser@2 & Glu $\rightarrow$ Ser@71 & \\
\hline SEEGVPISSGGF & & & 3 \\
\hline SEEGVPISSGGF & Glu $\rightarrow$ Ser@2 & Glu $\rightarrow$ Ser@71 & \\
\hline SEEGVPISSGGFGI & Glu $\rightarrow$ Ser@3 & Glu $\rightarrow$ Ser@72 & \\
\hline SEEGVPISSGGFGI & Glu $\rightarrow$ Ser@2 & Glu $\rightarrow$ Ser@71 & 2 \\
\hline SEEGVPISSGGFGIS & Glu $\rightarrow$ Ser@2 & Glu $\rightarrow$ Ser@71 & \\
\hline SEEGVPISSGGFGIS & & & 3 \\
\hline SFPQNTAVGS & Asn $\rightarrow$ His@5 & Asn $\rightarrow$ His@54 & 4 \\
\hline SFPQNTAVGS & Deamidated(N)@5 & & 4 \\
\hline SFPQNTAVGSSTS & Deamidated(N)@5 & & 2 \\
\hline SFPQNTAVGSSTSA & Deamidated(N)@5 & & \\
\hline SPVVVTLPG & $\begin{array}{c}\text { Oxidation }(\mathrm{P}) @ 8 ; \\
\text { Gly } \rightarrow \text { Cys@9; } \\
\text { Carbamidomethyl(C)@9 }\end{array}$ & $\begin{array}{c}\text { Oxidation(P)@44; } \\
\text { Gly } \rightarrow \text { Cys@45 }\end{array}$ & \\
\hline \multicolumn{4}{|l|}{ SPVVVTLPGP } \\
\hline SPVVVTLPGPILS & & & 3 \\
\hline SSFPQNTAVGS & Asn $\rightarrow$ His@6 & Asn $\rightarrow$ His@54 & 2 \\
\hline VIQPSPVVVTLP & Pro $\rightarrow$ Thr@4 & Pro $\rightarrow$ Thr@36 & \\
\hline VIQPSPVVVTLP & Ser $\rightarrow$ Ala@5 & Ser $\rightarrow$ Ala@37 & \\
\hline VPISSGGFGIS & & & \\
\hline
\end{tabular}


Table 5. Cont.

\begin{tabular}{|c|c|c|c|}
\hline Sequence & Modifications & Protein Modifications & $\begin{array}{c}\text { Number of } \\
\text { Repeats }\end{array}$ \\
\hline VVIQPSPV & & & 2 \\
\hline VVIQPSPVVV & Ser $\rightarrow$ Ala@6 & Ser $\rightarrow$ Ala@37 & 2 \\
\hline \multicolumn{4}{|l|}{ VVIQPSPVVV } \\
\hline VVIQPSPVVVTLP & $\begin{array}{c}\text { Pro } \rightarrow \text { Ser@5; } \\
\text { Oxidation(P)@7 }\end{array}$ & $\begin{array}{c}\text { Pro } \rightarrow \text { Ser@36; } \\
\text { Oxidation(P)@38 }\end{array}$ & \\
\hline VVIQPSPVVVTLP & $\begin{array}{l}\text { Oxidation(P)@5; } \\
\text { Pro } \rightarrow \text { Ser@7 }\end{array}$ & $\begin{array}{l}\text { Oxidation }(\mathrm{P}) @ 36 ; \\
\text { Pro } \rightarrow \text { Ser@38 }\end{array}$ & \\
\hline \multicolumn{4}{|l|}{ VVIQPSPVVVTLP } \\
\hline VVIQPSPVVVTLP & Ser $\rightarrow$ Val@6 & Ser $\rightarrow$ Val@37 & 4 \\
\hline VVIQPSPVVVTLP & Pro $\rightarrow$ Ser@7 & Pro $\rightarrow$ Ser@38 & \\
\hline VVIQPSPVVVTLP & Pro $\rightarrow$ Thr@5 & Pro $\rightarrow$ Thr@36 & \\
\hline VVIQPSPVVVTLP & Pro $\rightarrow$ Thr@7 & Pro $\rightarrow$ Thr@38 & 2 \\
\hline VVIQPSPVVVTLP & Pro $\rightarrow$ Ser@5 & Pro $\rightarrow$ Ser@36 & \\
\hline \multicolumn{4}{|l|}{ VVIQPSPVVVTLP } \\
\hline \multicolumn{4}{|c|}{ VVIQPSPVVVTLPGPILS } \\
\hline VVTLPGPILS & & & 2 \\
\hline VVVTLPGPILS & & & 3 \\
\hline \multicolumn{4}{|c|}{ P188D 20\% P2 } \\
\hline \multicolumn{4}{|l|}{ GPILSSFPQN } \\
\hline GLGSRFSGR & Arg $\rightarrow$ Ser@9 & Arg $\rightarrow$ Ser@93 & \\
\hline PVVVTLPGPILS & Pro $\rightarrow$ Thr@1 & Pro $\rightarrow$ Thr@38 & 2 \\
\hline PVVVTLPGPILS & Pro $\rightarrow$ Ser@1 & Pro $\rightarrow$ Ser@38 & 2 \\
\hline \multicolumn{4}{|c|}{ P188D 20\% P3 } \\
\hline GFGISGLGSR & Gly $\rightarrow$ Asn@3 & Gly $\rightarrow$ Asn@82 & \\
\hline GLGSRFSGR & Arg $\rightarrow$ Ser@9 & Arg $\rightarrow$ Ser@93 & \\
\hline
\end{tabular}

Table 6. Peptide sequence of the chicken feather microbial degradation present in the fraction P188D $40 \%$ P2 and P3 with $99 \%$ of confidence and its homology to chicken feather keratin 4.

\begin{tabular}{|c|c|c|}
\hline Sequence & Protein Modifications & $\begin{array}{c}\text { Number of } \\
\text { Repeats }\end{array}$ \\
\hline \multicolumn{3}{|c|}{ P188D 40\% P2 } \\
\hline \multicolumn{3}{|l|}{ EGVPISSGGFGIS } \\
\hline \multicolumn{3}{|l|}{ GFGISGLGSR } \\
\hline \multicolumn{3}{|l|}{ GGFGISGLGSR } \\
\hline \multicolumn{3}{|l|}{ GPILSSFPQ } \\
\hline \multicolumn{3}{|l|}{ GPILSSFPQN } \\
\hline \multicolumn{3}{|l|}{ GPILSSFPQNT } \\
\hline GPILSSFPQNTAVGS & Deamidated(N)@10 & \\
\hline \multicolumn{3}{|l|}{ GVPISSGGF } \\
\hline \multicolumn{3}{|l|}{ GVPISSGGFGI } \\
\hline \multicolumn{3}{|l|}{ GVPISSGGFGIS } \\
\hline IQPSPVVV & & \\
\hline
\end{tabular}


Table 6. Cont.

\begin{tabular}{|c|c|c|c|}
\hline Sequence & Modifications & Protein Modifications & $\begin{array}{c}\text { Number of } \\
\text { Repeats }\end{array}$ \\
\hline \multicolumn{4}{|l|}{ PSPVVVTLP } \\
\hline QDSRVVIQPSP & & Gln $\rightarrow$ pyro-Glu@N-term & \\
\hline SEEGVPISSGGF & Glu $\rightarrow$ Ser@2 & Glu $\rightarrow$ Ser@71 & \\
\hline \multicolumn{4}{|l|}{ SEEGVPISSGGFGIS } \\
\hline SFPQNTAVGSSTS & Deamidated(N)@5 & & \\
\hline \multicolumn{4}{|l|}{ SGGFGISGLGSR } \\
\hline \multicolumn{4}{|l|}{ SPVVVTLPGP } \\
\hline \multicolumn{4}{|l|}{ TLPGPILSSFPQ } \\
\hline \multicolumn{4}{|l|}{ VVIQPSPV } \\
\hline \multicolumn{4}{|l|}{ VVIQPSPVVV } \\
\hline \multicolumn{4}{|l|}{ VVIQPSPVVVTLP } \\
\hline \multicolumn{4}{|l|}{ VVTLPGPILS } \\
\hline \multicolumn{4}{|l|}{ VVVTLPGPIL } \\
\hline \multicolumn{4}{|l|}{ VVVTLPGPILS } \\
\hline PVVVTLPGP & Pro $\rightarrow$ Ser@1 & Pro $\rightarrow$ Ser@38 & \\
\hline SFPQNTAVGS & Asn $\rightarrow$ His@5 & Asn $\rightarrow$ His@54 & \\
\hline IQPSPVVVTLPGP & Ser $\rightarrow$ Pro@4 & Ser $\rightarrow$ Pro@37 & \\
\hline EEGVPISSGGF & Glu $\rightarrow$ Ser@2 & Glu $\rightarrow$ Ser@72 & \\
\hline VIQPSPVVVTLP & Ser $\rightarrow$ Ala@5 & Ser $\rightarrow$ Ala@37 & \\
\hline SRVVIQPSP & Arg $\rightarrow$ Asp@2 & Arg $\rightarrow$ Asp@31 & \\
\hline SPVVVTLPG & $\begin{array}{c}\text { Oxidation }(\mathrm{P}) @ 8 ; \\
\text { Gly } \rightarrow \text { Cys@9; } \\
\text { Carbamidomethyl(C)@9 }\end{array}$ & $\begin{array}{c}\text { Oxidation(P)@44; } \\
\text { Gly } \rightarrow \text { Cys@45 }\end{array}$ & \\
\hline VPISSGGF & PhosphoHexNAc(S)@5 & PhosphoHexNAc(S)@78 & \\
\hline IQPSPVVVTLP & $\begin{array}{c}\text { Oxidation(P)@3; } \\
\text { Pro } \rightarrow \text { Ala@5 }\end{array}$ & $\begin{array}{c}\text { Oxidation(P)@36; } \\
\text { Pro } \rightarrow \text { Ala@38 }\end{array}$ & \\
\hline EEGVPISSGGF & Glu $\rightarrow$ Ser@1 & Glu $\rightarrow$ Ser@71 & \\
\hline EGVPISSGGFGIS & & & 2 \\
\hline \multicolumn{4}{|l|}{ EGVPISSGGFGIS } \\
\hline \multicolumn{4}{|l|}{ GGFGISGLGSR } \\
\hline GPILSSFPQ & & & 4 \\
\hline GPILSSFPQN & & & 4 \\
\hline GPILSSFPQNT & & & 2 \\
\hline GPILSSFPQNTAVGS & Deamidated(N)@10 & & 2 \\
\hline GPILSSFPQNTAVGS & Asn $\rightarrow$ His@10 & Asn $\rightarrow$ His@54 & 3 \\
\hline GVPISSGGF & & & 3 \\
\hline GVPISSGGFGIS & & & 3 \\
\hline IQPSPVVV & Ser $\rightarrow$ Pro@4 & Ser $\rightarrow$ Pro@37 & \\
\hline IQPSPVVV & Pro $\rightarrow$ Glu@5 & Pro $\rightarrow$ Glu@38 & \\
\hline SEEGVPISSGGF & Glu $\rightarrow$ Lys@2 & Glu $\rightarrow$ Lys@71 & \\
\hline
\end{tabular}


Table 6. Cont.

\begin{tabular}{|c|c|c|c|}
\hline Sequence & Modifications & Protein Modifications & $\begin{array}{c}\text { Number of } \\
\text { Repeats }\end{array}$ \\
\hline SEEGVPISSGGF & & & 2 \\
\hline SEEGVPISSGGFGIS & & & 0.038 \\
\hline SFPQNTAVGS & Asn $\rightarrow$ His@5 & Asn $\rightarrow$ His@54 & \\
\hline SFPQNTAVGS & Deamidated(N)@5 & & \\
\hline SPVVVTLPG & $\begin{array}{c}\text { Oxidation(P)@8; } \\
\text { Gly } \rightarrow \text { Cys@9; } \\
\text { Carbamidomethyl(C)@9 }\end{array}$ & $\begin{array}{c}\text { Oxidation(P)@44; } \\
\text { Gly } \rightarrow \text { Cys@45 }\end{array}$ & \\
\hline SPVVVTLPGP & & & 2 \\
\hline \multicolumn{4}{|l|}{ TLPGPILSSFPQ } \\
\hline TLPGPILSSFPQ & Leu $\rightarrow$ Phe@2 & Leu $\rightarrow$ Phe@43 & \\
\hline VVIQPSPVVV & Ser $\rightarrow$ Ala@6 & Ser $\rightarrow$ Ala@37 & 3 \\
\hline VVTLPGPILS & & & 4 \\
\hline VVTLPGPILS & Leu $\rightarrow$ Phe@4 & Leu $\rightarrow$ Phe@43 & \\
\hline \multicolumn{4}{|l|}{ VVVTLPGPIL } \\
\hline VVVTLPGPILS & & & 4 \\
\hline \multicolumn{4}{|c|}{ P188D 40\% P3 } \\
\hline GFGISGLGSR & Gly $\rightarrow$ Asn@3 & Gly $\rightarrow$ Asn@82 & \\
\hline
\end{tabular}

Analysing the fraction P188D 20\% it was detected the presence of amino-acid sequences similar to the ones present in keratin 3 and 4 (Table 3). The presence of the two keratins ( 3 and 4 ) seems to decrease the migration and metabolic activity of the keratinocytes. In the P188D $40 \%$ fraction only the presence of sequences related to keratin 4 were found (Table 4). The loss of peptides with the homology to keratin 3 in P188D 40\% results in keratinocytes with a behaviour similar to the control. It can be hypothesized that the presence of peptides with homology to keratin 3 may be responsible for cell migration and metabolic activity decrease. Keratins are known to be intermediate filament-forming proteins that are related to differentiation status [40] and are known to be crucial for the motile processes, although is not fully clear [41].

The proteomics analysis detected any peptides for the fractions P188D 40\% P1, P4 and P5 related to chicken keratin feathers. In the case of fractions P188D 20\% P1, 40\% P2 and 40\% P3, all the peptides present had homology to chicken feather keratin 4 with some modifications on the sequence resulting in changes in the protein, as can be seen in Tables 5 and 6.

The peptides present in the fraction P188D 20\% P2 had homology to feather keratin 1 and 4, while $20 \%$ P3 has a homology to the chicken feather keratin 3 . The results obtained for migration or metabolic activity were not possible to correlate with the presence or absence of the peptides with homology to the keratin 3; this may be due to the loss of some of the peptide with particular sequences.

Nevertheless, this study demonstrates the ability to modulate keratinocyte migration and metabolic activity in the presence of different peptide sequences with homology to keratin.

\section{Conclusions}

This study demonstrated that the microbial degradation of chicken feathers has significant advantages. It is an environmentally friendly method to obtain bioactive peptides. The resulting peptides induced significant changes in the viability and migration rate of keratinocytes. The effect observed was dependent on the size distribution (fraction). The distinct effect of the peptides, depending on their fraction, opens doors to tailor-made 
medicine, where it is possible to modulate the cell's response, either to increase or decrease their migration rate and metabolic activity. The production of TNF- $\alpha$ was not exacerbated by the presence of the keratin peptides if there was a pre-activation of macrophages. On the other hand, P188D 40\% and P188D 20\% P1 significantly increased TNF- $\alpha$ production when placed in contact with non-activated macrophages. If these peptides are placed in contact with macrophages in their non-activated state, they will induce the production of an inflammatory cytokine. On the other hand, if the macrophages are already activated, the presence of the peptides will not exacerbate the condition.

The size as well as the sequence of the peptides present influences the cellular response, so on this project, the sequence of the peptides was determined and compared to Gallus gallus feather keratin. It was not possible to correlate the result obtained in terms of migration rate or metabolic activity, even though it was observed that the different peptides collections had homology to different Gallus gallus feather keratin. This fact may be due to changes present in a particular peptide sequence. Nevertheless, this study demonstrates the ability to modulate keratinocyte migration and metabolic activity in the presence of different peptide sequences with homology to keratin.

The work presented here is a step forward on the understanding of keratin peptides' influence on keratinocytes and immune cells system cells, macrophages, opening doors to tailor-made medicine.

Author Contributions: Conceptualization, C.M.B. and J.A.T.; methodology, C.M.B. and D.T.; formal analysis, C.M.B., H.O., P.S., A.C.-B. and P.F.-S.; investigation, C.M.B. and H.D.; resources, D.T. and N.S.; writing-original draft preparation, C.M.B.; writing—review and editing, C.M.B., J.A.T., D.T., P.S., A.C.-B. and P.F.-S.; funding acquisition, J.A.T. All authors have read and agreed to the published version of the manuscript.

Funding: This research was funded by the Portuguese Foundation for Science and Technology (FCT) under the scope of the strategic funding of UIDB/04469/2020 unit. It was also was financed by the Portuguese Mass Spectrometry Network, integrated in the National Roadmap of Research Infrastructures of Strategic Relevance (ROTEIRO/0028/2013; LISBOA-01-0145-FEDER-022125) and the MAC 2014-2020-MAC/1.1b/042-INTERREG V A España-Portugal, “BIOTRANSFER 2: Transferencia de la investigación biotecnológica orientada a rentabilidad empresarial y movilización de flujos de negocio $2^{\prime \prime}$.

Institutional Review Board Statement: Not applicable.

Informed Consent Statement: Not applicable.

Data Availability Statement: Not applicable.

Conflicts of Interest: The authors declare no conflict of interest.

\section{References}

1. Food and Agriculture Organization (FAO). World Agriculture: Towards 2015/2030_Perspective, An Fao; Food and Agriculture Organization (FAO): Rome, Italy, 2003.

2. Šafarič, R.; Zemljič, L.F.; Novak, M.; Dugonik, B.; Bratina, B.; Gubeljak, N.; Bolka, S.; Strnad, S. Preparation and characterisation of waste poultry feathers composite fibreboards. Materials 2020, 13, 4964. [CrossRef]

3. Sharma, S.; Gupta, A.; Chik, S.M.S.T.; Kee, C.G.; Mistry, B.M.; Kim, D.H.; Sharma, G. Characterization of keratin microparticles from feather biomass with potent antioxidant and anticancer activities. Int. J. Biol. Macromol. 2017, 104, 189-196. [CrossRef] [PubMed]

4. Tesfaye, T.; Sithole, B.; Ramjugernath, D.; Chunilall, V. Valorisation of chicken feathers: Characterisation of chemical properties. Waste Manag. 2017, 68, 626-635. [CrossRef] [PubMed]

5. Council of the European Union. Council Directive Council Directive 1999/31/EC on the landfill Waste. Off. J. Eur. Communities 1999, 182, 1-19.

6. Transforming Our World: The 2030 Agenda for Sustainable Development I Department of Economic and Social Affairs. Available online: https://sdgs.un.org/2030agenda (accessed on 22 June 2021).

7. Wang, J.; Hao, S.; Luo, T.; Cheng, Z.; Li, W.; Gao, F.; Guo, T.; Gong, Y.; Wang, B. Feather keratin hydrogel for wound repair: Preparation, healing effect and biocompatibility evaluation. Colloids Surf. B Biointerfaces 2017, 149, 341-350. [CrossRef]

8. Shavandi, A.; Silva, T.H.; Bekhit, A.A.; Bekhit, A.E.-D.A. Keratin: Dissolution, extraction and biomedical application. Biomater. Sci. 2017, 5, 1699-1735. [CrossRef] 
9. Yin, X.C.; Li, F.Y.; He, Y.F.; Wang, Y.; Wang, R.M. Study on effective extraction of chicken feather keratins and their films for controlling drug release. Biomater. Sci. 2013, 1, 528-536. [CrossRef]

10. Holkar, C.R.; Jain, S.S.; Jadhav, A.J.; Pinjari, D.V. Valorization of keratin based waste. Process Saf. Environ. Prot. 2018, 115, 85-98. [CrossRef]

11. Ramakrishnan, N.; Sharma, S.; Gupta, A.; Alashwal, B.Y. Keratin based bioplastic film from chicken feathers and its characterization. Int. J. Biol. Macromol. 2018, 111, 352-358. [CrossRef] [PubMed]

12. Feroz, S.; Muhammad, N.; Ranayake, J.; Dias, G. Keratin-Based materials for biomedical applications. Bioact. Mater. 2020, 5, 496-509. [CrossRef]

13. McKittrick, J.; Chen, P.Y.; Bodde, S.G.; Yang, W.; Novitskaya, E.E.; Meyers, M.A. The structure, functions, and mechanical properties of keratin. JOM 2012, 64, 449-468. [CrossRef]

14. Gniadecki, R. Regulation of keratinocyte proliferation. Gen. Pharmacol. 1998, 30, 619-622. [CrossRef]

15. Moll, R.; Divo, M.; Langbein, L. The human keratins: Biology and pathology. Histochem. Cell Biol. 2008, 129, 705-733. [CrossRef] [PubMed]

16. Giroud, A.; Leblond, C.P. The keratinization of epidermis and its derivatives, especially the hair, as shown by $\mathrm{x}$-ray diffraction and histochemical studies. Ann. N. Y. Acad. Sci. 1951, 53, 613-626. [CrossRef] [PubMed]

17. Sun, T.T.; Green, H. Keratin filaments of cultured human epidermal cells. Formation of intermolecular disulfide bonds during terminal differentiation. J. Biol. Chem. 1978, 253, 2053-2060. [CrossRef]

18. Martin, P. Wound Healing-Aiming for Perfect Skin Regeneration. Science 1997, 276, 75-81. [CrossRef]

19. Paladini, R.D.; Takahashi, K.; Bravo, N.S.; Coulombe, P.A. Onset of re-epithelialization after skin injury correlates with a reorganization of keratin filaments in wound edge keratinocytes: Defining a potential role for keratin 16. J. Cell Biol. 1996, 132, 381-397. [CrossRef]

20. Sampson, M.N.; Gooday, G.W. Involvement of chitinases of Bacillus thuringiensis during pathogenesis in insects. Microbiology 1998, 144, 2189-2194. [CrossRef] [PubMed]

21. Trepat, X.; Chen, Z.; Jacobson, K. Cell Migration. In Comprehensive Physiology; Wiley: Hoboken, NJ, USA, 2012; Volume 2, pp. 2369-2392.

22. Yamaguchi, H.; Wyckoff, J.; Condeelis, J. Cell migration in tumors. Curr. Opin. Cell Biol. 2005, 17, 559-564. [CrossRef]

23. Sivamani, R.K.; Garcia, M.S.; Rivkah Isseroff, R. Wound re-epithelialization: Modulating keratinocyte migration in wound healing. Front. Biosci. 2007, 12, 2849-2868.

24. Natarajan, E.; Omobono, J.D.; Guo, Z.; Hopkinson, S.; Lazar, A.J.F.; Brenn, T.; Jones, J.C.; Rheinwald, J.G. A Keratinocyte Hypermotility/Growth-Arrest Response Involving Laminin 5 and p16INK4A Activated in Wound Healing and Senescence. Am. J. Pathol. 2006, 168, 1821-1837. [CrossRef]

25. Pastar, I.; Stojadinovic, O.; Yin, N.C.; Ramirez, H.; Nusbaum, A.G.; Sawaya, A.; Patel, S.B.; Khalid, L.; Isseroff, R.R.; Tomic-Canic, M. Epithelialization in Wound Healing: A Comprehensive Review. Adv. Wound Care 2014, 3, 445-464. [CrossRef]

26. Rogers, H.W.; Weinstock, M.A.; Feldman, S.R.; Coldiron, B.M. Incidence Estimate of Nonmelanoma Skin Cancer (Keratinocyte Carcinomas) in the US Population, 2012. JAMA Dermatol. 2015, 151, 1081. [CrossRef]

27. Nagarajan, P.; Asgari, M.M.; Green, A.C.; Guhan, S.M.; Arron, S.T.; Proby, C.M.; Rollison, D.E.; Harwood, C.A.; Toland, A.E. Keratinocyte Carcinomas: Current Concepts and Future Research Priorities. Clin. Cancer Res. 2019, 25, 2379-2391. [CrossRef] [PubMed]

28. Karami, Z.; Akbari-adergani, B. Bioactive food derived peptides: A review on correlation between structure of bioactive peptides and their functional properties. J. Food Sci. Technol. 2019, 56, 535-547. [CrossRef] [PubMed]

29. Riss, T.L.; Moravec, R.A.; Niles, A.L.; Duellman, S.; Benink, H.A.; Worzella, T.J.; Minor, L. Cell Viability Assays; Eli Lilly \& Company and the National Center for Advancing Translational Sciences: Bethesda, MD, USA, 2004.

30. De Donatis, A.; Ranaldi, F.; Cirri, P. Reciprocal control of cell proliferation and migration. Cell Commun. Signal. 2010, 8, 20. [CrossRef]

31. Cheng, F.; Eriksson, J.E. Intermediate Filaments and the Regulation of Cell Motility during Regeneration and Wound Healing. Cold Spring Harb. Perspect. Biol. 2017, 9, a022046. [CrossRef] [PubMed]

32. Zhang, X.; Yin, M.; Zhang, L. Keratin 6, 16 and 17-Critical Barrier Alarmin Molecules in Skin Wounds and Psoriasis. Cells 2019, 8, 807. [CrossRef]

33. Neagu, M.; Constantin, C.; Caruntu, C.; Dumitru, C.; Surcel, M.; Zurac, S. Inflammation: A key process in skin tumorigenesis (Review). Oncol. Lett. 2018, 17, 4068-4084. [CrossRef]

34. Vyas, D.; Laput, G.; Vyas, A. Chemotherapy-enhanced inflammation may lead to the failure of therapy and metastasis. Onco. Targets. Ther. 2014, 7, 1015. [CrossRef] [PubMed]

35. Gao, J.; Zhang, L.; Wei, Y.; Chen, T.; Ji, X.; Ye, K.; Yu, J.; Tang, B.; Sun, X.; Hu, J. Human hair keratins promote the regeneration of peripheral nerves in a rat sciatic nerve crush model. J. Mater. Sci. Mater. Med. 2019, 30, 82. [CrossRef] [PubMed]

36. Mosser, D.M.; Edwards, J.P. Exploring the full spectrum of macrophage activation. Nat. Rev. Immunol. 2008, 8, 958-969. [CrossRef] [PubMed]

37. Mantovani, A.; Sica, A.; Sozzani, S.; Allavena, P.; Vecchi, A.; Locati, M. The chemokine system in diverse forms of macrophage activation and polarization. Trends Immunol. 2004, 25, 677-686. [CrossRef] [PubMed] 
38. Gordon, S.; Martinez, F.O. Alternative activation of macrophages: Mechanism and functions. Immunity 2010, 32, 593-604. [CrossRef] [PubMed]

39. Waters, M.; VandeVord, P.; Van Dyke, M. Keratin biomaterials augment anti-inflammatory macrophage phenotype in vitro. Acta Biomater. 2018, 66, 213-223. [CrossRef]

40. Herrmann, H.; Foisner, R. Intermediate filaments: Novel assembly models and exciting new functions for nuclear lamins. Cell. Mol. Life Sci. 2003, 60, 1607-1612. [CrossRef]

41. Hohmann, D. The Cytoskeleton-A Complex Interacting Meshwork. Cells 2019, 8, 362. [CrossRef] [PubMed] 